\title{
Antalya'da Yer Alan Konaklama Tesisleri Yöneticilerinin COVID-19 Kapsamında Alınabilecek Tedbirler Üzerine Görüşleri (The Views of The Managers of The Accommodation Facilities in Antalya on The COVID- 19 Scope)
}

\author{
Yusuf DÜNDAR (iD a Cemal Ersin SİLIK iD b Burcu ILGAZ iD c \\ a Jandarma ve Sahil Güvenlik Akademisi, Ankara, Türkiye. ysfdundar42@gmail.com \\ b Ankara Hacı Bayram Veli Üniversitesi, Turizm Fakültesi, Turizm İşletmeciliği Bölümü, Ankara, Türkiye. cemal.silik@hbv.edu.tr \\ c Akdeniz Üniversitesi, Manavgat Meslek Yüksekokulu, Seyahat-Turizm ve Eğlence Hizmetleri Bölümü, Antalya, Türkiye. \\ burcuilgaz@akdeniz.edu.tr
}

\begin{tabular}{|c|c|}
\hline MAKALE BİLGİSİ & ÖZET \\
\hline $\begin{array}{l}\text { Anahtar Kelimeler: } \\
\text { COVID-19 } \\
\text { Salgin } \\
\text { Konaklama işletmeleri } \\
\text { Tedbir }\end{array}$ & $\begin{array}{l}\text { Amaç - Korona virüs (COVID-19) olarak tanımlanan ve kısa sürede tüm dünyayı etkisi altına alan } \\
\text { salgından olumsuz etkilenen sektörlerden birisi de turizmdir. Özellikle konaklama işletmelerinin } \\
\text { faaliyetlerini durdurmak zorunda kalması, salgına yönelik alınması gereken tedbirlerin önemini } \\
\text { arttırmıştır. Bu araştırmanın amacı, Antalya'da yer alan konaklama tesisi yöneticilerinin COVID-19 } \\
\text { salgını kapsamında alınabilecek temel tedbirlere yönelik görüşlerini belirlemektir. }\end{array}$ \\
\hline $\begin{array}{l}\text { Gönderilme Tarihi } 6 \text { Temmuz } \\
2020 \\
\text { Revizyon Tarihi } 21 \text { Kasım } 2020 \\
\text { Kabul Tarihi } 10 \text { Aralık } 2020\end{array}$ & $\begin{array}{l}\text { Yöntem - Belirlenen amaç doğrultusunda, araştırma evrenini Antalya'da bulunan beş yıldızlı } \\
\text { konaklama tesislerinin yöneticileri oluşturmaktadır. COVID-19 salgını nedeniyle katılımcılarla yüz } \\
\text { yüze görüşme imkanı bulunmadığından görüşmeyi kabul eden } 13 \text { otel genel müdürü ile farklı } \\
\text { zaman dilimlerinde iletişime geçilerek internet ortamında online görüşme yapılmıştır. Araştırma, } \\
\text { nitel araştırma yöntemlerinden görüşme tekniği kullanılarak gerçekleştirilmiştir. Bu kapsamda, } \\
\text { görüşme yaklaşımlarından ise standartlaştırılmış açık uçlu görüşme yaklaşııı kullanılmıştır. } \\
\text { Araştırma verilerinin analizinde nitel veri analizlerinden içerik analizi kullanılmıştır. Veriler, } \\
\text { MAXQDA programı yardımıyla analiz edilmiştir. }\end{array}$ \\
\hline $\begin{array}{l}\text { Makale Kategorisi: } \\
\text { Araştırma Makalesi }\end{array}$ & $\begin{array}{l}\text { Bulgular - Araştırma sonuçlarına göre konaklama tesislerinde ön büro, yiyecek-içecek ve kat } \\
\text { hizmetleri başta olmak üzere tüm operasyonel birimlerde alınması gereken temel tedbirler } 4 \text { tema } \\
\text { (ön büro hizmetlerine, yeme-içme hizmetlerine, kat hizmetlerine ve diğer hizmetlere yönelik } \\
\text { alınabilecek temel tedbirler) ve } 43 \text { başlık altında toplanmışır. }\end{array}$ \\
\hline & $\begin{array}{l}\text { Tartışma - Çalışmanın sonucunda elde edilen başlıklar ve içerikler göstermektedir ki otel } \\
\text { yönetimleri korona virüs sonrası "yeni normal" olarak adlandırılan dönemde hijyen faaliyetlerine } \\
\text { otelin her biriminde oldukça önem vermektedir. Bu durum potansiyel turistlerin otelde konaklamak } \\
\text { için güvensizlik algılarının kırılmasına yardımcı olabilecek niteliktedir. }\end{array}$ \\
\hline
\end{tabular}

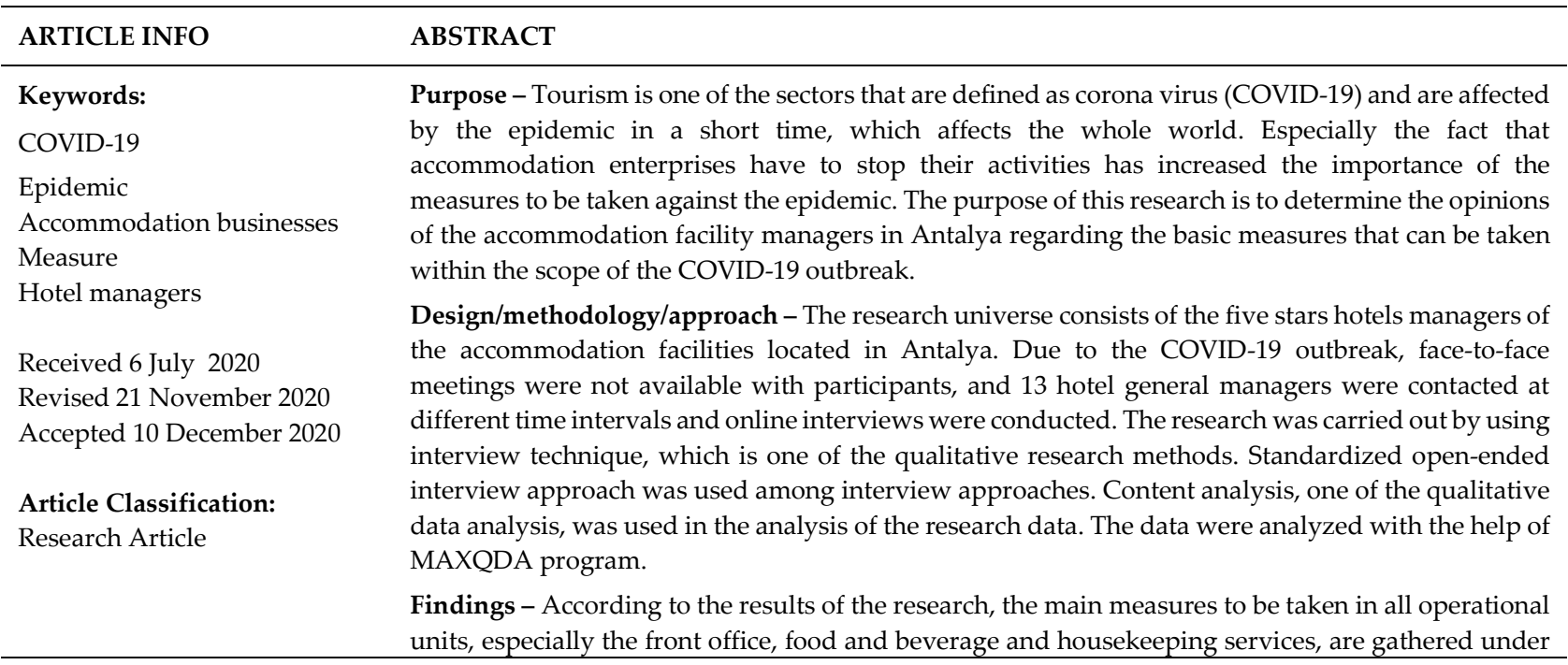


4 themes (basic measures that can be taken for front office services, food and beverage services, housekeeping and other services) and 43 topics.

Discussion - The titles and contents obtained as a result of the study show that hotel management pays great attention to hygiene activities in every unit of the hotel in the period called "new normal" after the corona virus. This can help potential tourists break their sense of insecurity to stay at the hotel.

\section{Giriş}

Turizm sektörü ülke ekonomileri için oldukça önemli bir yere sahiptir. Aynı zamanda yapısı bakımından ülke içerisinde veya dünyada meydana gelen olumsuz durumlardan ilk etkilenen sektörlerden birisidir. Doğal felaketler, siyasi belirsizlikler, terör ve ekonomik dalgalanmalar gibi ani meydana gelebilecek olaylar, turizm sektörünü doğrudan olumsuz olarak etkileyen çevresel faktörlerdendir. 2019 yılı Aralık ayının sonlarında Çin'in Wuhan şehrinde ortaya çıkan COVID-19 adı verilen salgın, her sektörü etkilediği gibi turizm sektörünü de derinden etkilemiştir. Dünya, İkinci Dünya Savaşı dönemlerinden bu yana bu kadar büyük bir salgınla yüzleşmemiştir. Herhangi bir önlem imkânı tanımadan hızla yayılan bu salgının insanlık tarihinde derin bir iz birakması beklenmektedir.

Turizm sektörü; insanlara insan ile hizmet sunmayı öngören ve üretildiği bölgede tüketilen ürün çıktısına sahip bir sektördür. Bu bakımdan sektör, bölgeler arası hareketliliği oldukça yoğunlaştırmaktadır. Salgın hastalıklar, diğer felaketler gibi insanların destinasyonlara olan güvensizlik algısına ve yoğun kaygı yaşamalarına sebep olmaktadır. Dolayısıyla potansiyel turistler kötü algılarının baskın gelmesi ile turistik etkinliklere katılım durumlarını erteleyebilmektedir. Turist tercihlerinin de ötesinde salgın ile birlikte ülkelerin turizm sektörüne yönelik almış oldukları kararlar hareketliliği ortadan kaldırmaktadır.

Turizm sektörü, küresel ölçekte salgın hastalıklarından doğrudan etkilenen önde gelen sektörlerden biridir. Salgınların, ülkelerin turizm gelirlerinde azalma meydana getirdiği ve turizm sektörünün toparlanmasının zaman aldığı bilinmektedir (Çeti ve Ünlüönen, 2019). Salgın ile birlikte ülkelerin sınırlarını kapatmaları, seyahat kısıtlarının ortaya çıkması, özellikle metropol şehirlerde sokağa çıkma yasaklarının uygulanması turizmin özünde yer alan yer değiştirme olayını ortadan kaldırmaktadır. Dolayısıyla 2020 yılının turizm sektörü bakımından küresel ölçekte büyük kayıplar oluşturacağı öngörülmektedir. Salgının uzun bir süre daha bu şekilde seyir edeceğinin öngörülmesi, ülkeleri, turistik işletmeleri ve turistleri salgına karşı gerekli tedbirleri alarak hareket etmeye mecbur bırakmaktadır. Özellikle turizmin ekonomi içerisinde önemli bir yer tuttuğu tüm ülkeler, konaklama ve seyahat sektöründe çeşitli tedbirler getirerek turizmi canlı tutma hedefini gütmektedir (Silik vd., 2020).

Turistik destinasyonlar ve bu destinasyonlarda faaliyet gösteren işletmeler, salgından sonra turistik çekiciliklerini korumak-artırmak için oldukça etkin bir atılım göstermek durumundadır. Alınacak tedbirler, potansiyel turistlerin güvensizlik algılarını değiştirebilmekte ve onları yeniden seyahate yöneltebilmek için bir etken olabilmektedir. Bu bağlamda yapılan bu çalışmanın amacı; turizm sektörü açısından en önemli yere sahip olan konaklama işletmelerinin COVID-19 salgını kapsamında alacakları temel tedbirlere yönelik görüşlerini analiz etmektir.

Çalışma, Antalya'da yer alan beş yıldızlı otel yöneticileri ile görüşülerek gerçekleştirilmiştir. Çalışmanın gerçekleştirildiği 01-24 Nisan 2020 tarihleri arasında, konaklama tesislerinin alması gereken tedbir paketlerinin henüz gerçekleştirilmemiş olduğunu belirtmek gerekmektedir. Bu nedenle, işletme yöneticileri bireysel tedbir görüşlerini belirtmiştir. Tesislerin salgın dolayısıyla otel içerisinde alacakları önleyici etkinlikler sorulmuştur. Pandemi sebebiyle tesis yöneticileri ile yüz yüze bir görüşme gerçekleştirilememiş, bu görüşmeler online platformda yapılmıştır. Görüşmeye 13 otel yöneticisi olumlu olarak dönüş yapmıştır. Çalışmada öncelikle literatür incelemesi yapılmış ve konu ile ilgili alanyazında yer alan diğer çalışmalar incelenmiştir. Sonrasında ise COVID-19 ile ilgili kavramsal çerçeveye yer verilmiş, yöntem, bulgular ve sonuç kısımları ile çalışma tamamlanmıştır.

\section{Literatür İncelemesi}

Literatür incelemesi sonucunda, salgının yakın zamanda ortaya çıkması ve etkisinin halen tüm dünyada yaygın bir biçimde hissedilmesi nedeniyle sınırlı sayıda çalışmaya rastlanılmıştır. Literatüre kısa süre içerisinde kazandırılan bu çalışmalar, salgının farklı konu alanlarına yönelik etkilerini açıklamaktadır. Bu 


\section{Y. Dündar - C. E. Silik - B. Ilgaz 12/4 (2020) 3776-3794}

kapsamda salgının; sosyo-ekonomik (Nicola vd., 2020), gündelik hayat (Haleem vd., 2020), çevre (Wang ve Su, 2020; Zambrano-Monserrate vd., 2020), iletişim ve sosyal medya (Yu vd., 2020) ile turizm (Gössling vd., 2020; Yang vd., 2020; Hoefer vd., 2020; Demir vd., 2020) alanlarına yönelik etkilerini içeren çalışmalar literatürde tartışılmıştır.

Küresel ölçekte etkili olan salgın ve salgının ortaya çıkan etkileri ile ilgili kısa zamanda birçok çalışma literatüre kazandırılmıştır. Salgının etkileri, farklı pozisyonlarda çalışan kişilerin (yönetici, personel, akademisyen vs.) bakış açıları ile ele alınmıştır. Özellikle salgının; otel çalışanları bakış açısı ile etkilerine (Soehardi ve Untari, 2020; Jung vd., 2021), turizm akademisyenleri perspektifinden etkilerine (Türker, 2020; Kiper vd., 2020) ve insan kaynakları uzmanı veya yöneticileri tarafından algılanan etkilerine (Tuna ve Çelen, 2020) yönelik literatürde çalışmalara rastlanılmıştır. Filimonau ve diğerleri (2020) tarafından yapılan çalışmada ise, salgının otel yöneticileri bakış açısı ile etkileri incelenmiştir. Karadeniz vd., (2020) tarafından yapılan benzer çalışmada, salgının turizm sektörüne etkileri otel yöneticileri bakış açısıyla ele alınmıştır. Elde edilen sonuçlar incelendiğinde, salgının turizm sektörü üzerindeki en büyük etkilerinin yüksek gelir ve istihdam kaybı olacağı tespit edilmiştir. Bununla birlikte, otel işletmelerinin Sağlık Bakanlığı ile Kültür ve Turizm Bakanlığı tarafından yayımlanan genelgeler doğrultusunda önlemler aldıkları belirlenmiştir (Karadeniz vd., 2020). Bu çalışmada ise, Bakanlıklar tarafından çıkan genelgeler öncesinde otel yöneticilerinin alınacak tedbirlere yönelik görüşleri incelendiğinden karşılaştırma yapma imkânı doğmuştur. Yapılan karşılaştırma sonucunda, otel yöneticilerinin alınmasını istediği tedbirler ile genelgede yayımlanan tedbirlerin örtüştüğü görülmektedir. Ayrıca Erdoğan ve Yamaç Erdoğan (2020) tarafından yapılan başka bir çalışmada ise, Türkiye Cumhuriyeti Kültür ve Turizm Bakanı Mehmet Nuri Ersoy'un Nisan ayında turizmde normalleşme faaliyetlerine yönelik yapmış olduğu beş kamuoyu bilgilendirmesi incelenmiştir. Elde edilen sonuçlar, temelinde hijyen olan sertifikasyon sisteminin yerleşik hale getirilmesini, finansman ve istihdam desteklerinin ön planda tutulmasını içermektedir (Erdoğan ve Yamaç Erdoğan, 2020). Elde edilen sonuçlar ile bu çalışma karşılaştıııldığında, otel yöneticilerinin de temelinde hijyen olan sertifikasyon sistemini destekledikleri ve sonuçların örtüştüğü söylenebilmektedir.

Şengel vd., (2020) tarafından yapılan çalışmada, COVID-19'un konaklama sektörü üzerindeki etkileri hem müşteriler hem de işletme yöneticileri perspektifi ile ele alınmıştır. Elde edilen sonuçlar salgının, kısa vadede kriz yönetimi ve psikoloji açısından işletmeleri etkilediğini ortaya koymaktadır. Salgından sonra işletmelerin, geceleme, gelir, gelen misafir ve doluluk oranlarında hem grup hem de bireysel satışlarda ciddi düşüşler yaşadığı gözlenmiştir (Şengel vd., 2020).

COVID-19 salgınının Jakarta'daki otel çalışanları üzerindeki etkilerinin incelendiği çalışmada (Soehardi ve Untari, 2020), salgının otellerdeki doluluk oranlarını azalttığı ve bunun sonucunda da otellerde çalışan personelin \% 30-40 oranında azaldığı tespit edilmiştir. Çalışmada, salgın nedeniyle daha detaylı istenen sağlık protokolünün, otellerde çalışan işçi sayısını olumsuz yönde etkilediği belirtilmiştir. Bununla birlikte Jung ve diğerleri (2021) tarafından delux otel çalışanlarına yapılan çalışmada, salgının çalışanlar üzerinde iş güvensizliğine neden olduğu ve bunun da personelin işe bağlılığını olumsuz etkilediği sonucuna varılmıştır.

Salgının etkileri, turizm akademisyenleri perspektifinden incelendiğinde Türker (2020) tarafından yapılan çalışmada, daha çok hijyen, sosyal mesafe, yeni standartlar ve dijitalleşme, kitle turizmi yerine bireysel turizm, doğa turizmi gibi kavramların ön plana çıktığı görülmektedir. Benzer bir biçimde Kiper ve diğerleri (2020) tarafından yapılan çalışmada turizm akademisyenlerinin, salgın dolayısı ile sektörde ciddi kayıplar yaşanabileceği endişesine sahip olduğu belirlenmiştir. Ayrıca çalışmaya katılan turizm akademisyenlerinin çoğunluğu, salgın nedeniyle aksayan turizm hareketliliğinin 1-2 yıl içerisinde normal seyrine dönebileceğini belirtmiştir.

Tuna ve Çelen (2020) tarafından yapılan çalışmada salgın, insan kaynakları yöneticileri bakış açısıyla ele alınmıştır. İnsan kaynakları yöneticileri, salgın ile ilgili özellikle işletmelerin uygulamalarında internet sistemlerine ağırlık vermesi gerekliliğini ortaya koymaktadır. Ayrıca, çalışanlara yönelik hijyen ve sağlık kontrollerinin gerçekleştirilmesi, sağlanan destek, kredi ve işletme imkanları ile çalışanlara iş güvencesi sağlanması gerekliliği de belirtilmiştir. Bununla birlikte Jiang ve Wen (2020) tarafından yapılan çalışmada, COVID-19'un otel yönetim uygulamaları üzerindeki etkileri tartışılmıştır. Özellikle çalışmada, internet tabanlı pazarlama ve yönetim uygulamalarının geliştirilmesi vurgulanmıştır. COVID-19'un küresel ölçekte otellerdeki işleyişi değiştirdiği ve işletmelerin hayatta kalmalarını etkilediği sonucuna varılmıştır. 


\section{Y. Dündar - C. E. Silik - B. Ilgaz 12/4 (2020) 3776-3794}

Hoefer ve diğerleri (2020) tarafından yapılan çalışmada, salgının otel işletmelerindeki yönetimine ilişkin bir örnek ortaya konulmuştur. Tenerife'deki (İspanya) bir otelde bulunan İtalyan bir misafire yönelik yapılan virüs testinin pozitif çıkması ile birlikte otel karantinaya alınmıştır. Hızlı tespit ve alınan önlemler ile daha büyük bir vaka sayının oluşumunun önüne geçilmiştir. Çalışmada hızlı tespitin ve otel işletmesindeki kriz yönetiminin önemi vurgulanmaktadır. COVID-19 salgınının İspanya'daki üst düzey otel yöneticilerinin örgütsel bağlılığına etkisini ortaya koyan çalışmada Filimonau ve diğerleri (2020), işletmelerin salgına yönelik alacağı tedbirlerin algılanan iş güvenliğini arttıracağı ve bunun da yöneticilerin örgütsel bağl1lıklarına olumlu katkı sağlayacağı tespit edilmiştir.

Gössling ve diğerleri (2020) tarafından yapılan çalışmada ise, salgının turizm sektörüne etkileri ve salgının sebep olduğu küresel değişim değerlendirilmiştir. Salgın ile birlikte ortaya çıkan seyahat kısıtlamaları, sokağa çıkma yasakları vb. uygulamaların, II. Dünya Savaşı'ndan bu yana küresel ekonomiye en ciddi zararı verdiği belirtilmiştir. Çalışmada, dünya nüfusunun \% 90'ından fazlasını etkileyen seyahat kısıtlamalarının, 2020 yılının Mart ayında dünyadaki turizm hareketliliğini büyük ölçüde durdurduğu ifade edilmektedir. COVID19 salgını ile diğer küresel kriz türlerinin karşılaştırıldığı çalışmada salgının, devam eden küresel iklim krizinin bir türevi olabileceği tartışılmaktadır. Bununla birlikte, küresel boyuttaki turizm organizasyonları tarafından ortaya çıkartılacak bir turizm büyüme modeline (sürdürülebilir turizm modeli) duyulan ihtiyaç sorgulanmaktadır.

Demir ve diğerleri (2020) tarafından yapılan çalışmada, salgının Türkiye'deki turizm sektörü üzerindeki etkileri incelenmiştir. Çalışmada, işletmeler açısından ekonomik sorunların sosyal sorunlardan daha önemli olduğu sonucu ortaya çıkmıştır. Ayrıca turizm işletmelerinin, kriz yönetimi konusunda deneyimsiz olmaları nedeniyle gerçekçi ve uygulanabilir bir plan ortaya koyamadıkları tespit edilmiştir. Elde edilen sonuçlar ile birlikte, konaklama tesislerinin düşük kapasitede hizmet verebilecekleri, kalabalık yerlerden ziyade daha sakin tatil yerlerinin tercih sebebi olacağı, ülke içi seyahatlerde özel araçlara yönelimin artacağı, büyük otellerin çok uluslu müşterilerden uzaklaşarak belirli bir hedef pazara yöneleceği, turizmde maliyetlerin artacağı ve artan maliyetlerin de tatil fiyatlarını yükselteceği öngörülmektedir. Ayrıca Arslan ve Kendir (2020) tarafından yapılan çalışmada, COVID-19 salgını neticesinde ortaya çıkan sosyal mesafe kuralları ve bireysel hareket etme tavsiyeleri nedeniyle, turizm aktivitelerinin daha çok kırsalda yapılacak olan aktivitelerden meydana geleceği öngörülmektedir (Arslan ve Kendir, 2020).

Yapılan literatür incelemesi sonucunda, COVID-19 salgınına yönelik otel yöneticilerinin öncelikleri arasında hijyen, iş güvenliği ve güvencesi, internet tabanlı hizmetin yaygınlaştırılması gibi konuların geldiği anlaşılmaktadır. Özellikle otel yöneticileri, işletmelerde salgına karşı birtakım tedbirlerin alınması gerekliliğini vurgulamaktadır. Bu noktada ise, otel yöneticilerinin salgına karşı alınması gereken tedbirlerde ön planda yer alması gerekmektedir. Bu çalışma, konaklama tesislerindeki yöneticilerin, salgına karşı alınması gereken tedbirlere yönelik görüşlerini ortaya koyduğu için gerek teorik gerekse de pratik olarak önemli katkılar sunmaktadır. Araştırma sonuçlarına göre konaklama tesislerinde ön büro, yiyecek-içecek ve kat hizmetleri başta olmak üzere tüm operasyonel birimlerde alınması gereken temel tedbirler 4 tema (ön büro hizmetlerine, yeme-içme hizmetlerine, kat hizmetlerine ve diğer hizmetlere yönelik alınabilecek temel tedbirler) ve 43 başlık altında toplanmıştır.

\section{COVID-19 Salgını ile İlgili Kavramsal Çerçeve}

\subsection{COVID-19 Salginı}

2019 yılının Aralık ayında Çin'in Hubei eyaletine bağlı Vuhan şehrinde ortaya çıkan korona virüsü (COVID19), kısa bir süre içerisinde küresel boyutta bir salgın haline gelmiştir. T.C. Sağlık Bakanlığı tarafından yapılan tanıma göre korona virüsleri, insanlarda veya hayvanlarda çeşitli hastalıklara yol açabilecek büyük bir virüs çeşididir. Korona virüsü, insanlar üzerinde soğuk algınlığı, Orta Doğu Solunum Sendromu (MERS) ve Şiddetli Akut Solunum Sendromu (SARS) gibi çeşitli solunum yolu enfeksiyonlarına sebebiyet vermektedir. Yeni korona virüsü hastalığına, SARS-CoV-2 virüsünün neden olduğu ifade edilmektedir. 7 Ocak 2020 tarihinde Dünya Sağlık Örgütü tarafından yeni tip bir korona virüsü (2019-nCoV) olarak belirlenmiştir. Sonrasında ise hastalığın adı, COVID-19 olarak kabul edilmiştir (www.tursab.org.tr). Aralık 2019'da Çin'de ortaya çıkan COVID-19, tüm dünyaya yayılarak bir salgın haline gelmiştir. Konuyla ilgili yapılan çalışmalar, salgının küresel tedarik zincirini, üretimi, ticareti ve piyasaları, dolayısıyla ekonominin genel dinamiklerini bozduğunu ortaya koymaktadır (Orhan ve Tırman, 2020). 


\section{Y. Dündar - C. E. Silik - B. Ilgaz 12/4 (2020) 3776-3794}

Birleşmiş Milletler Dünya Turizm Örgütü tarafından yayınlanan, turizmin yeniden başlaması için küresel tedbirler raporunda, COVID-19 salgınının 2020 yılı içerisinde turizm sektörüne olası etkileri ele alınmıştır. Kılavuza göre, 2020 yılı projeksiyonunda turizm sektöründe faaliyet gösteren 100 milyondan 120 milyona kadar iş, risk altında bulunmaktadır. İhracatta 910 milyar dolardan 1.2 trilyon dolara kadar kayıp beklenmektedir. Ayrıca kılavuzda 2020 yılı için uluslararası turist sayısının 850 milyon ile 1.1 milyar arasında bir kayba uğrayacağı ifade edilmektedir (UNWTO, 2020).

Birleşmiş Milletler Dünya Turizm Örgütü, 2020 yılı içerisinde salgının durumuna bağlı olarak, uluslararası turizm faaliyetlerinde \% 58 ile \% 78 arasında değişen bir gerilemenin yaşanacağını ifade etmektedir. Bu duruma yönelik örgüt tarafından üç farklı senaryo ortaya koyulmuştur. Buna göre, sinırlardaki kapatmalar ve seyahat yasakları Temmuz ayı başında kademe kademe kaldırılmaya başlanırsa \% 58'lik (birinci senaryo); Eylül ayı başında kaldırılmaya başlanırsa \% 70'lik (ikinci senaryo); Aralık ayı başında kaldırılmaya başlanırsa da \% 78'lik (üçüncü senaryo) bir düşüş öngörülmektedir (www.tursab.org.tr).

Dünya Sağlık Örgütü tarafından yayınlanan COVID-19 verilerine göre, 7 Haziran 2020 tarihi itibariyle 6.750.521 tespit edilmiş vaka bulunmaktadır. Bununla birlikte, salgından ölenlerin sayısı da 395.779'dur. Bölgelere göre kıyaslama yapıldığında, en fazla vakalar sırasıyla Amerika (3.203.995 tespit edilmiş vaka) ve Avrupa (2.249.999 tespit edilmiş vaka) Bölgesindedir. Ülkelere göre değerlendirme yapıldığında ise, en fazla tespit edilmiş vakalar sırasıyla Amerika (1.886.794), Brezilya (614.941), Rusya (458.689), İngiltere (283.315), Hindistan (246.628), İspanya (240.978), İtalya (234.531), Peru (187.400), Almanya (183.678), İran (169.425), Türkiye (168.340) ve Fransa'da (149.495) görülmektedir (www.covid19.who.int). T.C. Sağlık Bakanlığ1 tarafından yayınlanan COVID-19 tablosuna göre, 7 Haziran 2020 tarihi itibariyle Türkiye'de tespit edilmiş toplam 170.132 vaka bulunmaktadır. Toplam vefat edenlerin sayısı ise 4.692' dir (www.covid19.saglik.gov.tr).

\subsection{Turizm Sektöründe Alınan Tedbirler}

COVID-19 ile ilgili tedbirler kapsamında, en erken önlem alan ülkelerden birisi de Türkiye olmuştur. Bu kapsamda, kaynağa yönelik, bulaşma yoluna yönelik ve sağlam kişiye yönelik önlemler alınmıştır (Dilber ve Dilber, 2020). COVID-19 salgınına yönelik Türkiye'de farklı alanlarda birçok tedbirler alınmaktadır. Bu tedbirlerin başında; şehirlerarası seyahat kısıtlaması, eğitimde derslerin online verilmesi, esnek çalışma saatleri, alışveriş merkezlerinin geçici olarak kapatılması, maske takma zorunluluğu ve özellikle hafta sonları dışarıya çıkma kısıtlamaları gelmektedir. Ayrıca konaklama işletmeleri özelinde de birtakım tedbirler alınmıştır. Bunların başında ise; personellerin hijyen kurallarına azami ölçüde uymaları, klimaların bakım ve onarımlarının yapılması, oyun alanlarındaki oyuncakların kaldırılması, sauna, masaj ve spor salonlarının kullanılmaması, odaların temizlik sonrası en az 1 saat havalandırılması, personelin tek kullanımlık eldivenler kullanması gelmektedir (www.covid19bilgi.saglik.gov.tr).

COVID-19 salgını kapsamında yerli ve yabancı ziyaretçileri korumak ve sağlıklı bir tatil deneyimi sunmak için T.C. Kültür ve Turizm Bakanlığı'nın öncülüğünde, Sağlık, Ulaştırma, İçişleri ve Dışişleri Bakanlıklarının katkıları ve sektörde yer alan tüm paydaşların katkısı ile birlikte "Güvenli Turizm Sertifikasyon Programı" başlatılmıştır. Bu kapsamda, ulaşımdan konaklamaya, çalışan personelden konukların kendi sağlık durumlarına kadar birçok alanda bir dizi tedbir belirlenmiştir. Konaklama ve yeme-içme tesisleri, farklı kriterler çerçevesinde uluslararası standartlarda denetime tabi tutularak sağliklı bir hizmet sunması amaçlanmaktadır. İnsanların tatile çıkmaya çekindiği böyle bir salgın sürecinde, sertifikasyon programının başlatılması işletmeleri belirli tedbirleri almaya teşvik etmektedir. Özellikle konaklama tesisleri kapsamında; zorunlu uygulamalar, misafirlerin otele girişleri, personele yönelik tedbirler, genel alanlarda (yatak odası, mutfak, yeme-içme üniteleri, yüzme havuzu, fitness salonu, animasyon salonları) düzenlemeler, güvenlik önlemleri, otel taşıtları, personel lojmanları, satın alma, haşere ve zararlılarla mücadele, atık yönetimi, acil durum ve izolasyon gibi konu başlıklarında bir dizi kriterler yer almaktadır. Örneğin misafirlerin otele giriş zamanlarında, sosyal mesafe konusunda bilgilendirilmeleri, gerekli dezenfektanların lobide bulunması, ödemelerde mümkün olduğunca temassız ödeme yapılması, kullanım tekrarı olan malzemelerde (oda kartı, havlu kartı, resepsiyon zili vb.) gerekli dezenfektenin yapılıp uygun şekilde muhafaza edilmesi, odalardaki ürünlerin (kumanda, isıtıcı vb.) her misafirden sonra iyi bir şekilde dezenfekte edilmesi, odaların havalandırma işlemlerinin sıklıkla yapılması, odanın havalandırma işlemi tamamlanmadan diğer müşterilere verilmemesi, odalarda genellikle tek kullanımlık malzemelerin tercih edilmesi gibi hususlar kriterlerden bazılarıdır (www.tga.gov.tr). 


\section{Y. Dündar - C. E. Silik - B. Ilgaz 12/4 (2020) 3776-3794}

Güvenli Turizm Sertifikasyon Programı çerçevesinde 9 Haziran 2020 tarihi itibariyle Türkiye genelinde sertifika sahibi (belgesi verilen) 31 konaklama tesisi bulunmaktadır. Belge sahibi bu tesislerin bulunduğu iller incelendiğinde, en fazla belge sahibi tesislerin Antalya (10 tesis), İstanbul (6 tesis), Ankara (4 tesis), Trabzon (4 tesis), Muğla (2 tesis), Balıkesir (2 tesis), Gaziantep (1 tesis), Sakarya (1 tesis) ve Bursa'da (1 tesis) olduğu görülmektedir. Antalya şehri, belge sahibi en fazla konaklama tesisinin bulunduğu destinasyondur. Antalya' da 9 Haziran 2020 tarihi itibariyle sertifika sahibi 10 konaklama tesisi bulunmaktadır. Bu tesisler Tablo 1 'de yer almaktadır.

Tablo 1. Güvenli Turizm Sertifikasyon Programı Kapsamında Sertifika Alan Konaklama Tesisleri*

\begin{tabular}{|l|l|c|c|}
\hline \multicolumn{1}{|c|}{ Tesis Ad1 } & \multicolumn{1}{|c|}{ Denetleyici Firma } & İl/İçe & Sertifika Tarihi \\
\hline $\begin{array}{l}\text { Sueno Deluxe Belek \& Golf } \\
\text { Belek }\end{array}$ & $\begin{array}{l}\text { TSE Sistem Belgelendirme } \\
\text { Grup Başkanlığ1 }\end{array}$ & Antalya/Serik & 28.05 .2020 \\
\hline Grand Park Lara Hotel & $\begin{array}{l}\text { Royalcert Belgelendirme ve } \\
\text { Gözetim Hizmetleri A.Ş. }\end{array}$ & Antalya/Aksu & 02.06 .2020 \\
\hline Goldcity Otel & $\begin{array}{l}\text { TSE Sistem Belgelendirme } \\
\text { Grup Başkanlı̆̆1 }\end{array}$ & Antalya/Alanya & 02.06 .2020 \\
\hline Crown Plaza & $\begin{array}{l}\text { Royalcert Belgelendirme ve } \\
\text { Gözetim Hizmetleri A.Ş. }\end{array}$ & Antalya/Konyaaltı & 03.06 .2020 \\
\hline Gold Island & $\begin{array}{l}\text { TSE Sistem Belgelendirme } \\
\text { Grup Başkanlığı }\end{array}$ & Antalya/Alanya & 03.06 .2020 \\
\hline Khan Otel & $\begin{array}{l}\text { BV Inspektorate Uluslararası } \\
\text { Gözetim Servisleri A.Ş. }\end{array}$ & Antalya/Muratpaşa & 04.06 .2020 \\
\hline Grandpark Kemer & $\begin{array}{l}\text { Royalcert Belgelendirme ve } \\
\text { Gözetim Hizmetleri A.Ş. }\end{array}$ & Antalya/Kemer & 05.06 .2020 \\
\hline Corner Park & $\begin{array}{l}\text { Royalcert Belgelendirme ve } \\
\text { Gözetim Hizmetleri A.Ş. }\end{array}$ & Antalya/Konyaaltı & 05.06 .2020 \\
\hline $\begin{array}{l}\text { Rixos Hotel Premium Belek } \\
\text { Otel }\end{array}$ & $\begin{array}{l}\text { LLYOD'S Register Gözetim } \\
\text { Ltd. Şti. }\end{array}$ & Antalya/Serik & 05.06 .2020 \\
\hline Ak-ka Hotels Antedon & $\begin{array}{l}\text { BV Inspektorate Uluslararası } \\
\text { Gözetim Servisleri A.Ş. }\end{array}$ & Antalya/Kemer & 07.06 .2020 \\
\hline
\end{tabular}

Kaynak: https://ktb.gov.tr

*09 Haziran 2020 tarihli listedir. Liste sürekli güncellenmektedir.

Tablo 1'de yer alan tesislerin haricinde Antalya bölgesinde belgelendirme sürecinde bulunan toplam 106 tesis bulunmaktadır. Türkiye genelinde ise belgelendirme sürecinde bulunan toplam 272 konaklama tesisi bulunmaktadır. Belge sahibi tesisler, sürekli olarak Bakanlığın sayfasında ilan edilerek liste güncellenmektedir.

Birleşmiş Milletler Dünya Turizm Örgütü tarafından 28 Mayıs 2020 tarihinde COVID-19 salgınına karşı turizm sektöründeki iyileşme önceliklerine yönelik küresel bir kılavuz hazırlanmıştır. Hazırlanan kılavuzda, sınır yönetimi, özel sektör, ulaşım, konaklama, tur hizmetleri, organizasyonlar, tema parklar ve destinasyon yönetimi gibi alanlarda alınması gerekli olan tedbirler belirtilmiştir. Salgının, özellikle konaklama sektörü üzerindeki etkilerini minimize etmek için hijyen ve operasyon, ürün ve pazarlama, ortaklıklar konu başlıklarında birtakım küresel tedbirler açıklanmıştır. Buna göre konaklama sektöründe hijyen ve operasyonlar ile ilgili alınması gereken tedbirlerden bazıları şu şekildedir: Ortak alanlardaki temizlik sıklığı arttırmak, konukları, temizlik ve alınan tedbirler hususunda sıklıkla bilgilendirmek, elektrostatik ve ultraviyole ışıklar gibi yeni yöntemleri keşfetmek, konuklara temassız bir check-in ortamı sağlamak ve hijyen kiti (maske, dezenfektan gibi) temin etmek, konuklar ile doğrudan ve hızlı bir biçimde iletişim sağlamak için teknolojik sistemleri kullanmaktır (UNWTO, 2020).

Konaklama sektöründe, ürün ve pazarlama ile ilgili alınması gereken tedbirler ise şu şekildedir: Paket servisi, yemek dağıtımı, aile deneyimleri, ortak çalışma alanları gibi yeni hizmet kanallarını eklemek, yerel üreticileri destekleyerek kısa vadede iç turizmi harekete geçirmek, yerli üretici ve çalışanları desteklemek için pazarlama kampanyaları uygulamaktır. Son olarak, konaklama sektöründeki ortaklıklar ile ilgili alınması gereken tedbirler şunlardır: Sağlık sektöründe yer alan ve sağlık hizmetlerini tedarik eden firmalar ile işbirliği yapmak, 
sağlık merkezleri veya kuruluşları ile işbirliği yapmak, destinasyon yönetim organizasyonları ile işbirliği yaparak koordineli çalışmaktır (UNWTO, 2020).

1 Haziran 2020 tarihi itibariyle Türkiye'de korona virüs salgın sürecinde yeni normalleşme dönemine geçilmiştir. Bu tarihten itibaren, plajlar, parklar, millet bahçeleri, müzeler, mesire alanları, kafeler, lokantalar, spor salonları gibi birçok yer yeniden açılmıştır. Fakat açılan tüm yerler ve alanlar için özel kurallar düzenlenmiştir. Bu kuralların başında, sosyal mesafenin (en az 1,5 metre) muhafaza edilmesi, maskesiz dışarıya çıkılmaması ve hijyen kurallarına azami düzeyde uyulması gelmektedir. Bu tarihten itibaren oteller de belirli kurallar çerçevesinde müşteri kabul etmektedir. Özellikle yeni normalleşme dönemi ile beraber seyahat yasaklarının da kalkmasının turizm faaliyetlerine canlılık getirmesi beklenmektedir. Nitekim Kültür ve Turizm Bakanlığı tarafından yapılan açıklamada, seyahat kısıtlarının olduğu 2020 yılı Nisan-MayısHaziran aylarında Türkiye'ye gelen toplam ziyaretçi sayısı 349.907 kişi iken, seyahat kısıtlamalarının kalktığ1 Temmuz-Ağustos-Eylül aylarında Türkiye'ye gelen toplam ziyaretçi sayısı 6.108.431 kişi olmuştur (Kültür ve Turizm Bakanlığı, 2020d). Elde edilen sonuçlar, seyahat kısıtlamalarının turizm faaliyetlerini ne düzeyde etkilediğini ortaya koymaktadır.

\subsection{Konaklama İşletmelerinde Alınan Tedbirler}

Türkiye Otelciler Birliği (TÜROB) işbirliği ile STR Global şirketi tarafından 2020 yılının Mart ayında otel doluluk verileri araştırılmıştır. Salgının küresel etkisiyle birlikte dünya genelindeki otel doluluk oranlarında ciddi düşüşlerin yaşandığı belirlenmiştir. Özellikle Avrupa Bölgesinde 2020 yılının Mart ayında otel doluluk oranları \% 26.3'lük bir ortalamada kalmıştır. Ortaya çıkan bu tablo, II. Dünya savaşından bu yana yaşanan en kötü tabloyu oluşturmaktadır (www.tursab.org.tr). Türkiye'de ise, 2020 yılı Mart ayı otel doluluk oranı, 2019 yılının aynı dönemine göre \% 55.2 azalarak, \% 28.6 olarak kaydedilmiştir (www.dunya.com). Yaşanan bu durumun kısa sürede toparlanabilmesi için konaklama sektörü özelinde tedbirlerin alınması zorunluluk haline gelmiştir. Dolayısıyla her ülke kendine yönelik bazı tedbirler geliştirmiştir. Türkiye'de konaklama sektörü özelinde alınan tedbirler, T.C. Kültür ve Turizm Bakanlığı öncülüğünde uygulanmaktadır.

T.C. Kültür ve Turizm Bakanlığı tarafından 12 Mayıs 2020 tarihinde "Konaklama Tesislerinde Kontrollü Normalleşme Süreci" hakkında 2020/6 sıra sayılı genelge yayınlanmıştır. Genelgenin kapsamında, salgın ile ilgili ortaya konulan başarılı mücadelenin sonrasında, seyahat ve turizm faaliyetlerinin sağlıklı bir şekilde yeniden aktif hale getirilmesine yönelik birtakım tedbirler de yer almaktadır. Bu tedbirler, genel ilkeler, misafir kabulü, genel kullanım alanları, personel ve genel temizlik konu başlıklarında belirtilmektedir. İlgili konu başlıklarında yer alan bazı önemli tedbirler aşağıda açıklanmıştır. İlk olarak genelgede, genel ilkeler ile ilgili bazı bilgilendirmeler yapıldıktan sonra konaklama tesislerinin misafir kabulüne yönelik aşağıda belirtilen tedbirlere uygun hareket etmesi istenmiştir (www.ktb.gov.tr):

o Sosyal mesafe kuralları muhafaza edilerek belirlenmiş kapasitede misafir kabulü,

o Tesis girişinde termal kamera veya temassız ateş ölçüm uygulamaları,

o Dezenfeksiyon halıları, misafirlere yönelik koruyucu ekipmanlar (maske, vb.),

o Temassız ödeme işlemleri.

Genel kullanım alanlarına yönelik alınması istenilen tedbirler şu şekildedir:

o Asansörlerin sosyal mesafe kuralına uygun kullanılması,

o Lobi, yemek salonları, havuz başı alanlar, oturma alanları, gösteri alanları vb. tüm açık ve kapalı alanların sosyal mesafe planına uygun bir biçimde düzenlenmesi,

o Tesis içerisindeki çocuk oyun alanlarının, oyun odalarının, çocuk kulübünün kapalı tutulması,

o Genel kullanım alanlarının ve genel müşteri tuvaletlerinin girişlerinin otomatik düzenek ile hazırlanması, mümkün olmayan durumlarda ise paravan kullanılarak giriş kapılarının açık tutulması,

o Jimnastik veya spor salonu gibi ünitelerin açılması durumunda rezervasyon sistemi ile çalışılması, kişi sayısı ve süre sınırının getirilmesi ve bu ünitelerde tek kullanımlık malzemelerin kullanılması,

o Hamam, sauna, SPA gibi ünitelerin "Sağlıklı Turizm Sertifikası" bulunmayan tesislerde kapalı tutulmasi,

o Genel alanlarda bulunan içecek istasyonlarının kaldırılması ve servis personellerinin bu iş için kullanilmasi,

o Yiyecek servisi verilen masalar arası mesafenin 1,5 metre, yan yana sandalyeler arası $60 \mathrm{~cm}$. olacak şekilde düzenlenmesi. 


\section{Y. Dündar - C. E. Silik - B. Ilgaz 12/4 (2020) 3776-3794}

Tesiste çalışan personellere yönelik alınması istenilen tedbirler ise şu şekildedir:

o Personelin düzenli sağlık kontrolü ve periyodik bilgisi,

o Tesis çalışanlarına salgın ve hijyen konularında özel eğitim verilmesi,

o Personel girişlerinde ateş ölçer takibinin yapılması,

o Aynı vardiyada mümkün olduğunca aynı personelin çalıştırılması,

o Personel ortak alanlarının sosyal mesafe kurallarına uygun hazırlanması,

o Satın alma veya başka sebeplerle (bakım, tamir vb.) tesise geçici olarak kabul edilen kişilerin temasının asgari düzeyde tutulmasi.

Konaklama tesislerinin, konukların sağlıklı ve güvenli bir şekilde hizmet alabilmesi için söz konusu tedbirlere uygun hareket etmesi gerekmektedir. Salgından her sektör gibi olumsuz bir şekilde etkilenen turizm sektörünün de alınan tedbirler ile birlikte yeniden canlanması amaçlanmaktadır.

02 Haziran 2020 tarihinde ise T.C. Kültür ve Turizm Bakanlığı tarafından "2020/6 Sıra Sayılı Konaklama Tesislerinde Kontrollü Normalleşme Süreci Genelgesi Değişikliği" konu başlığında 2020/9 sıra sayılı yeni bir genelge daha yayınlanmıştır. Söz konusu bu yeni genelgede ise bir önceki genelgede yapılan bazı değişiklikler belirtilmiştir. Bu kapsamda, çocuk kulübü, çocuk oyun odaları, lunapark, oyun alanları gibi ünitelerin T.C. Aile, Çalışma ve Sosyal Hizmetler Bakanlığınca belirlenen usul ve esaslardaki hijyen ve sağlık kurallarına uyulması şartıyla hizmete açılabileceği belirtilmiştir. Ayrıca mini kulüp girişlerinde, çocukların temassız ateş ölçümüne tabi tutulmaları, ateşi 38 dereceden yüksek olan çocukların aileleriyle iletişime geçilerek sağlık kuruluşlarına yönlendirilmeleri ifade edilmiştir. Bu ünitelerde klima ve vantilatörlerin çalıştırılmaması, sık sık kapı ve pencerelerinin açılarak doğal havalandırmalarının yapılması, sosyal mesafe kuralına azami ölçüde uyulması gerekliliği vurgulanmıştır. Bununla birlikte genelgede, hamam, SPA, sauna ve masaj ünitelerinin de T.C. İçişleri Bakanlığında belirlenen usul ve esaslardaki hijyen kurallarına uyulması şartıyla hizmet verebilmesine yönelik değişiklik yer almaktadır (www.tga.gov.tr).

\section{Yöntem}

\subsection{Araştırma Alanı}

Araştırma Antalya'da gerçekleştirilmiştir. Her ne kadar alternatif turizm türlerinin geliştirilmesine yönelik çabalar olsa da Türkiye'de iç ve dış turizm kıyı turizmi odaklı büyümektedir. Türkiye'nin güneyinde yer alan ve Akdeniz'e kıyısı bulunan Antalya Türkiye'de kıyı turizmin hâkim olduğu en popüler turistik destinasyonların başında gelmektedir. Sınır istatistiklerine göre 2019 yılında Türkiye'ye gelen 45.1 milyon yabancı ziyaretçinin 14.7 milyonuna (\% 32.5'ine) Antalya ev sahipliği yapmıştır. Bu yabancı ziyaretçi sayısı ile Antalya İstanbul'dan sonra (14.9 milyon) ikinci destinasyon olmuştur (Kültür ve Turizm Bakanlı̆̆ı, 2020a). İstanbul'da Türkiye'de hâkim olan kıyı turizminin gelişimi oldukça zayıftır. İç turizmde de Antalya 2019 yılında 4.4. milyon konaklama tesislerine geliş sayısı ile İstanbul'dan (4.7 milyon) sonra ikinci sırada yer almıştır.

2019 yılında Türkiye' de yerli turistlerin turizm işletme belgeli ve belediye belgeli konaklama tesislerine geliş sayısı 42 milyon olarak gerçekleşmiş ve Antalya 4.4. milyon ile \% 10.4 oranında bir pay almıştır. 2019 yılında yabancı turistlerin konaklama tesislerine geliş sayısı ise 38.9 milyon olarak gerçekleşmiş, Antalya 18.9 milyon konaklama tesislerine geliş sayısı (\% 48.6) ile birinci sırada yer almıştır. Yerli ve yabancı turistlerin toplam konaklama tesislerine geliş sayıları dikkate alındığında da Antalya 2019 yılında 23.2 milyon konaklama tesislerine geliş sayısı ile \% 28.7 pay alarak Türkiye' de birinci sırada yer almıştır. 2019 yılında Türkiye'de yerli ve yabancı turist konaklamalarının çoğu (\% 58.9'u) turizm işletme belgeli otellerde yapılmıştır. Turizm işletme belgeli otellerde yapılan konaklamaların büyük bir kısmı da (\% 49.2) beş yıldızlı otellerde yapılmıştır. Ülke genelindeki istatistiklere paralel olarak Antalya'da 2019 yılında yerli ve yabancı turist konaklamalarının çoğu (\% 73) turizm işletme belgeli otellerde yapılmıştır. Bu otellerde yapılan konaklamaların büyük bir kısmı da (\% 70.1'i) beş yıldızlı otellerde yapılmıştır (Kültür ve Turizm Bakanlığı, 2020b). Bu otellerde sadece oda, odakahvaltı, yarım pansiyon, tam pansiyon konseptleri ile kıyaslandığında her şey dâhil sistemi uygulaması oldukça yaygındır.

Türkiye'de 4.109 turizm işletme belgeli tesiste 479.553 oda ve 1.004 .248 yatak bulunmaktadır. 801 turizm işletme belgeli tesis, 214.414 oda ve 461.714 yatak sayısı ile Antalya tesis, oda ve yatak sayılarının hepsinde birinci sırada yer almaktadır. Ayrıca turizm işletme belgeli tesislere ilave olarak Türkiye'de 8.421 belediye 


\section{Y. Dündar - C. E. Silik - B. Ilgaz 12/4 (2020) 3776-3794}

belgeli tesiste 246.641 oda ve 563.112 yatak sayısı bulunmaktadır. Antalya 1.010 belediye belgeli tesis ile İstanbul'dan (1.331 tesis) sonra ikinci sirada, 51.318 oda sayıs1 ve 13.673 yatak sayıs1 ile birinci sirada yer almaktadır (Kültür ve Turizm Bakanlı̆̆ı, 2020c).

Türkiye'de ve Antalya'da bulunan konaklama tesislerinin çoğunu turizm işletme belgeli oteller oluşturmaktadır. Türkiye'de bulunan 3.019 turizm işletme belgeli otelin 675'i beş yıldızlı otellerdir. Antalya 672 turizm işletme belgeli otel sayısı ile en çok turizm işletme belgeli otele sahip şehirdir. Antalya'daki otellerin büyük kısmını (\% 50.1) oluşturan 337 otel beş yıldızlı oteldir. Türkiye'de bulunan beş yıldızlı otellerin yarısı Antalya'dadır (Türkiye Otelciler Birliği, 2020). Türkiye'de ve Antalya'da konaklama sektörü, bu kapsamda turizm işletme belgeli beş yıldızlı oteller turizm sektörünün en önemli bileşenini oluşturmaktadır.

\subsection{Evren ve Örneklem}

Araştırmanın evrenini Antalya'da bulunan beş yıldızlı otellerin genel müdürleri oluşturmaktadır. Antalya' da bulunan konaklama tesislerinin çoğunu turizm işletme belgeli oteller oluşturmaktadır. Bu otellerin büyük kısmını da beş yıldızlı oteller oluşturmaktadır. Beş yıldızlı otellerde ön büro, konaklama, yeme-içme gibi tüm operasyonel birimlerde görevlerin yerine getirilmesinde çeşitli kademelerde bulunan yöneticiler, kendi birimindeki en üst düzeydeki yöneticiye, o da genel müdüre, genel müdür de işletme sahibine karşı sorumludur. Yetki ve sorumlulukları bakımından genel müdürler, tüm operasyonel birimlerin işleyişine en çok hâkim olan ve oteldeki en üst düzeydeki kişilerdir. Bu nedenlerle, araştırma evrenini Antalya'da bulunan beş yıldızlı otellerin genel müdürleri oluşturmaktadır. Evren içerisinden bütünü temsil edebilecek bir örneklem grubu seçilip uygulama gerçekleştirilmiştir.

Antalya'da 337 beş yıldızlı otel bulunmaktadır. Çalışma kapsamında araştırma evreninin çok geniş olması ve bütün evrene ulaşılmasının imkânsız olması nedeniyle, gerek maliyet gerekse zaman açısından da değerlendirildiğinde evrenin tümü yerine evreni temsil eden bir örneklem üzerinden çalışılmıştır. Örneklem seçiminde basit tesadüfi örnekleme yöntemi kullanılmıştır. Basit rasgele örnekleme de denilen tesadüfi örneklemede, evrendeki öğelerin her olası birleşiminin, örneklem içinde yer alması için eşit bir ihtimali vardır (Kerlinger ve Lee, 1999). Nitel araştırmalarda ideal örneklem büyüklüğü, verilerin doyuma ulaştığ1 ve verilerin döngüsel olarak tekrarlanmaya başladığı noktadır (Guba ve Lincoln, 1982; Denzin ve Lincoln, 2008). Araştırma kapsamında örneklem seçiminde öncelikle Türkiye Otelciler Birliğinden (2020) Antalya' da bulunan turizm işletme belgeli konaklama tesislerinin listesine ulaşılmış, bu tesislerden beş yıldızlı oteller tespit edilerek 1 den 337'ye kadar numaralandırılmıştır. Listede sıra numarası 20 ve katları olan oteller örnekleme dâhil edilmiştir. Bu kapsamda 16 otel belirlenmiş ve bu otellerin genel müdürlerinden veriler toplanmıştır.

Araştırmacılar tarafından genel müdürler ile görüşme talebinde bulunmak için öncelikle otellerin kurumsal web sayfalarından kurumsal e-posta adresleri tespit edilmiştir. E-posta ile yapılması planlanan çalışma kısaca anlatılarak görüşme talebi iletilmiştir. COVID-19 salgını nedeniyle katılımcılarla yüz yüze görüşme imkanı bulunmadığından görüşmeyi kabul eden 13 genel müdür ile farklı zaman dilimlerinde iletişime geçilerek "Google Hangouts" üzerinden online görüşme yapılmıştır. Her bir görüşme ortalama 20-30 dakika sürmüştür. Yapılan görüşmeler, görüşme anında not edilerek kayıt altına alınmıştır. Görüşmeler 01-24 Nisan 2020 tarihleri arasında gerçekleştirilmiştir.

\section{3. Ölçme Araçları}

Araştırma nitel araştırma yöntemlerinden görüşme tekniği kullanılarak gerçekleştirilmiştir. Stewart ve Cash (1985) görüşmeyi "önceden belirlenmiş ve ciddi bir amaç için yapılan, soru sorma ve yanıtlama tarzına dayalı karşılıklı ve etkileşimli bir iletişim süreci" olarak tanımlamaktadırlar. Bu yöntemin seçilme nedeni, görüşme yapılan kişiden araştırma konusu ile derinlemesine bilgilerin alınmasını sağlamasıdır. Araştırma kapsamında elde edilmesi istenen verilerin görüşme yöntemi dışında sağlanmasının zorluğu da bu yöntemin seçilmesinde diğer bir etken olmuştur.

Patton (1987) sohbet tarzı görüşme, görüşme formu yaklaşımı ve standartlaştırılmış açık uçlu görüşme tarzı olarak üç tür görüşme yaklaşımından söz etmektedir. Bu araştırmada görüşme yaklaşımlarından standartlaştırılmış açık uçlu görüşme yaklaşımı kullanılmıştır. Bu yaklaşım "dikkatlice yazılmış ve belirli bir sıraya konmuş bir dizi sorudan oluşur ve her görüşülen bireye bu sorular aynı tarzda ve sırada sorulur" (Patton, 1987). Bu yaklaşım görüşmeciye tanınan esnekliğin epeyce sınırlanmasına rağmen görüşmeci yanlılığını ve öznelliğini azaltması nedeniyle seçilmiştir. 


\section{Y. Dündar - C. E. Silik - B. Ilgaz 12/4 (2020) 3776-3794}

Görüşme formu araştırmanın amacı doğrultusunda araştırmacılar tarafından geliştirilmiştir. Görüşme formunda 10 adet soru yer almıştır. Bu sorulardan 6'sı katılımcıların demografik özelliklerinin, çalışma hayatındaki deneyimlerinin ve çalıştıkları otelin konsepti ve konumunu belirlemek amacıyla sorulmuştur. Bu kapsamda katılımcıların sırasıyla cinsiyeti, yaşı, halen çalışmakta oldukları otelde ve turizm sektöründe kaç yıldır çalıştıkları ve otelin uyguladığı konsept ile otelin konuşlu bulunduğu turizm merkezi öğrenilmiştir. Diğer 4 soru ise genel müdürlerin operasyonel birimlerde COVID-19 kapsamında alınabilecek temel tedbirlere yönelik görüşlerinin alınması amacıyla hazırlanmıştır. Bunlar; Otelinizin hizmete başlaması ile birlikte salgın yayılımının önlenmesi maksadıyla ön büro hizmetlerinde alınması gereken temel önlemler nelerdir?, Otelinizin hizmete başlaması ile birlikte salgın yayılımının önlenmesi maksadıyla yiyecek-içecek hizmetlerinde alınması gereken temel önlemler nelerdir?, Otelinizin hizmete başlaması ile birlikte salgın yayılımının önlenmesi maksadıyla kat hizmetlerinde alınması gereken temel önlemler nelerdir? Otelinizin hizmete başlaması ile birlikte salgın yayılımının önlenmesi maksadıyla otelin diğer hizmetlerinde alınması gereken temel önlemler nelerdir? sorularından oluşmaktadır. Bu sorular araştırmacılar tarafından belirtilen sıra dâhilinde tüm katılımcılara sırası bozulmadan aynı şekilde sorulmuştur.

\subsection{Verilerin Analizi}

Araştırmada nitel araştırma yöntemlerinden görüşme tekniği kullanılmış, görüşme yaklaşımlarından ise standartlaştırılmış açık uçlu görüşme yaklaşımı kullanılmıştır. Elde edilen verilerin çözümünde, içerik analizi tekniğinden faydalanılmış ve bir paket program ile veriler çözümlenmiştir. Araştırma sonuçlarına göre konaklama tesislerinde ön büro, yiyecek-içecek ve kat hizmetleri başta olmak üzere tüm operasyonel birimlerde alınması gereken temel tedbirler 4 tema ve 43 başlık olarak bulgulanmıştır.

Verilerin analizinde nitel analizlerden içerik analizi kullanılmıştır. İçerik analizi yoluyla veriler tanımlanmaya, verilerin içinde saklı olabilecek gerçekler meydana çıkarılmaya çalışılmaktadır. İçerik analizinde yapılan temel işlem, birbirine benzeyen verileri belirli kavramlar (kodlar) ve temalar çerçevesinde bir araya getirmek ve elde edilen kod ve temaları okuyucunun anlayabileceği bir şekilde düzenlemektir.

Online görüşmelere tüm araştırmacılar katılmış, görüşmeler sırasında araştırmacılar tarafından kâğıt-kalem ile tutulan kayıtlar, her bir görüşmenin hemen ardından bilgisayar ortamına aktarılmıştır. Her bir araştırmacı tarafından bilgisayar ortamına alınan kayıtlar bir araştırmacı tarafından veri kaybının engellenmesi maksadıyla kontrol edilerek tek bir ortak metin olarak kayıt altına alınmıştır. Bu metin daha sonra her bir araştırmacı tarafından ayrı ayrı içerik analizine tabi tutulmuştur. Müteakiben analize tabi tutulan tüm metinler bir araştırmacı tarafından tekrar analiz edilerek metne nihai şekli verilmiştir.

Yukarıda belirtilen süreç boyunca içerik analizleri dört aşamalı okumayla yapılmıştır. Birinci aşamada bütün kayıt listesi dikkatli bir biçimde okunarak içerik hakkında bilgi sahibi olunmaya çalışılmıştır. İkinci tur okumada, her görüşme için belirlenen dört tema (ön büro hizmetleri, yiyecek-içecek hizmetleri, kat hizmetleri, diğer hizmetler) altında belirli başlıklar verilerek kodlama yapılmış ve birbirine benzeyen çok sayıdaki bilgi kümesi benzer başlıklar (kodlar) altında toplanmaya çalışılmıştır. Kalan veri kümesi üzerinde üçüncü ve son bir tur okuma daha yapılarak gözden kaçan veri olup olmadığı kontrol edilmiştir. Sürecin son aşamasında yapılan son bir kontrol ile her başlık (kod) altındaki metnin birbirleriyle uyumu ya da benzeşimi konusunda emin olmaya çalışılmıştır. Verilerin analizinde MAXQDA programından faydalanılmıştır.

\section{Bulgular}

\subsection{Katılımcıların Demografik Özellikleri, Deneyimleri ve Çalıştıkları Otele İlişkin Bulgular}

Görüşme formunda katılımcıların demografik özelliklerinin, çalışma hayatındaki deneyimlerinin ve çalıştıkları otelin konsepti ve konumunu belirlemek amacıyla yer alan 6 soruya yönelik verilen cevaplar doğrultusunda katılımcıların cinsiyeti, yaşı, halen çalışmakta oldukları otelde ve turizm sektöründe kaç yıldır çalıştıkları ve otelin uyguladığı konsept ile konuşlu bulunduğu turizm merkezlerine ilişkin bilgiler Tablo 2.'de sunulmuştur. Katılımcıların \% 69.2'sini erkekler, \% 30.8'ini kadınlar oluşturmaktadır. Katılımcıların yaş ortalaması $46.4^{\prime}$ dür. Katılımcıların turizm sektöründe toplam çalışma sürelerinin ortalaması 24.3, şu an görevli oldukları otelde çalışma sürelerinin ortalaması ise 6.2' dir. Katılımcıların görevli oldukları otellerin tamamında her şey dâhil sistemi uygulanmaktadır. Katılımcıların çalıştıkları otellerin büyük kısmı (\% 61.5) Manavgat ilçesi ve bağlı turistik merkezlerinde konuşlu bulunmaktadır. 
Y. Dündar - C. E. Silik - B. Ilgaz 12/4 (2020) 3776-3794

Tablo 2. Katılımcıların Demografik Özellikleri, Deneyimleri ve Çalıştıkları Otele İlişkin Bulgular

\begin{tabular}{|l|l|l|c|c|l|l|}
\hline Katılımcılar & Cinsiyet & Yaş & $\begin{array}{c}\text { Turizm } \\
\text { Sektöründe } \\
\text { Çalışma Süresi }\end{array}$ & $\begin{array}{c}\text { Görevli Olduğu } \\
\text { Otelde Çalışma } \\
\text { Süresi }\end{array}$ & $\begin{array}{c}\text { Otelin } \\
\text { Konsepti }\end{array}$ & $\begin{array}{c}\text { Bulunduğu } \\
\text { Turistik Merkez }\end{array}$ \\
\hline Katılımc1 1 & Kadın & 47 & 26 & 3 & Her şey dâhil & Manavgat \\
\hline Katılımc1 2 & Erkek & 47 & 22 & 1 & Her şey dâhil & Manavgat \\
\hline Katılımc1 3 & Kadın & 30 & 10 & 1 & Her şey dâhil & Kızılot/Manavgat \\
\hline Katılımc1 4 & Erkek & 33 & 15 & 4 & Her şey dâhil & Side/Manavgat \\
\hline Katılımc1 5 & Kadın & 43 & 22 & 2 & Her şey dâhil & Manavgat \\
\hline Katılımc1 6 & Kadın & 38 & 15 & 8 & Her şey dâhil & Manavgat \\
\hline Katılımc1 7 & Erkek & 51 & 32 & 11 & Her şey dâhil & Side/Manavgat \\
\hline Katılımc1 8 & Erkek & 49 & 29 & 4 & Her şey dâhil & Belek \\
\hline Katılımc1 9 & Erkek & 57 & 37 & 21 & Her şey dâhil & Side/Manavgat \\
\hline Katılımc1 10 & Erkek & 64 & 38 & 10 & Her şey dâhil & Kemer \\
\hline Katılımc1 11 & Erkek & 50 & 25 & 8 & Her şey dâhil & Belek \\
\hline Katılımc1 12 & Erkek & 48 & 23 & 4 & Her şey dâhil & Belek \\
\hline Katılımc1 13 & Erkek & 46 & 22 & 3 & Her şey dâhil & Belek \\
\hline
\end{tabular}

Tablo 2 incelendiğinde, araştırmaya katılanlarının tamamının turizm sektöründeki tecrübeli çalışanlardan meydana geldiği anlaşılmaktadır. Katılımcılar arasında en tecrübesiz olanın bile en az 10 yıldır turizm sektörünün içerisinde yer aldığı anlaşılmaktadır. En tecrübeli katılımcı ise 38 yıldır sektör içerisinde yer almaktadır. Tablo 2' de yer alan katılımcıların deneyimleri incelendiğinde ise, sektördeki iş gücü devir hızının yüksek olduğu anlaşılmaktadır. Yani turizm sektöründe çalışan personellerin çok sık işletme değiştirdikleri ifade edilebilir.

\subsection{COVID-19 Kapsamında Alınabilecek Temel Tedbirlere İlişkin Bulgular}

Görüşme formunda katılımcıların COVID-19 kapsamında alınabilecek temel tedbirlere yönelik görüşlerinin alınması maksadıyla hazırlanan 4 soruya verilen cevaplar "ön büro hizmetleri"ne yönelik alınabilecek temel tedbirler, "yeme-içme hizmetleri"ne yönelik alınabilecek temel tedbirler, "kat hizmetleri"ne yönelik alınabilecek temel tedbirler ve "diğer hizmetler"e yönelik alınabilecek temel tedbirler olmak üzere 4 tema altında toplanarak kodlanmıştır. Her bir departman için elde edilen sonuçlar, ayrı ayrı maddeler halinde açıklanmıştır.

\subsection{1. Ön büro hizmetlerine yönelik alınabilecek temel tedbirler}

Yapılan içerik analizi ile birlikte ön büro hizmetlerine yönelik alınabilecek temel tedbirler kapsamında 13 başlık (kod) belirlenmiştir. Yapılan çalışma sonucunda belirlenen başlıklar (kodlar) doğrultusunda alınabilecek temel tedbirler;

o Ateş ölçümü: Personelin ve misafirlerin otele girişte ateş ölçer ve/veya termal kamera ile ateşinin ölçülmesi,

- Fotoselli dezenfektan: Ellerin temizliği için uygun yerlere fotoselli dezenfektan standlarının kurulması,

o Dezenfeksiyon: Personel ve misafir kullanım alanlarının güçlü ve sağlığa zararlı olmayan dezenfeksiyon yöntemleri ile dezenfekte edilmesi,

o Maske dağıtımı: Yeni gelen ve maskesi olmayan misafirlere maske dağıtılması,

- Koruyucu malzeme: Ön büro personelinin maske, eldiven ve siperlik kullanması,

o Deskin muhafazası: Deske cam seperatör yapılarak ön büro personeli ile misafirin korunması,

o Fiziksel mesafenin korunması: C/in ve c/out işlemleri sırasında ve asansörlerde belirli işaretlerle, uyarılarla ve oturma alanlarının azaltılması suretiyle misafirler arasında fiziksel mesafe kuralına uyulmasının sağlanması,

o Numaratör: Gerektiğinde numaratör sisteminin kurularak c/in işlemlerinin sıra ile yapılması,

o Deskin bölünmesi: $\mathrm{C} /$ in ve c/out işlemleri için deskin paravan ile ayrılması,

o Ön büro malzemelerinin dezenfeksiyonu: C/in işlemleri sırasında kullanılabilecek malzemenin (pos cihazı, kapı kartları vb.) dezenfekte edilmesi, mümkünse temassız pos cihazının kullanılması, kapı kartları ve kalemlerin korumalı kılıflarda sunulması, kalemlerin tek kullanımlık şekilde hazırlanması,

o Online c/in: C/in işlemlerinin mümkünse online yapılabilmesi, 


\section{Y. Dündar - C. E. Silik - B. Ilgaz 12/4 (2020) 3776-3794}

o Bavulların taşınması: Bavulların taşınmasında bellboyların ayrı bir asansör kullanması, bavulların dezenfeksiyonu ve oda kapısı önüne bırakılması,

- Bilgilendirme: Misafirlerden salgın hakkında bilgi alış-verişinde bulunulması, misafirlerin hastalık durumu hakkında bilgi alınması ve salgına yönelik alınan tedbirler ve uygulamalar hakkında bilgilendirilmesi olarak sıralanabilir.

Ön büro departmanı, otel müşteri ile ilk temas edecek departman olduğu için bu kısımda alınacak tedbirler diğer departmanları da etkileyecektir. Otel yöneticileri tarafından elde edilen verilere göre, öncelikle otele giriş esnasında concierge birimi tarafından misafirlerin ateşlerinin ölçülmesi, maske kontrollerinin yapılması gerekliliği vurgulanmıştır. Ayrıca belirli aralıklarla dezenfeksiyon konulması da önem arz etmektedir. Otel yöneticilerinin görüşlerine göre, önbüro departmanında dikkat edilecek hususlardan birisi de önbüro personeli ile müş̧teriler arasında özellikle c/i işlemleri esnasında sosyal mesafenin korunması, mümkün ise deskin paravan ile ayrılmasıdır. Bununla birlikte c/i işlemlerinin, müşteriler tek tek alınarak yapılması gerekmektedir. Hatta c/i işlemlerinin internet aracıllı̆g ile yapılması duyurulmalı ve müşterilerin internet kullanımı teşvik edilmelidir. Son olarak, bellboy personelinin ayrı bir asansör kullanması, valizlerin dezenfektanını sağlaması ve müşteri valizlerini oda kapısına bırakması önerilmektedir.

\subsubsection{Yiyecek-içecek hizmetlerine yönelik alınabilecek temel tedbirler}

Yapılan içerik analizi ile birlikte yiyecek-içecek hizmetlerine yönelik alınabilecek temel tedbirler kapsamında 10 başlık (kod) belirlenmiştir. Yapılan çalışma sonucunda belirlenen başlıklar (kodlar) doğrultusunda alınabilecek temel tedbirler;

o Fiziksel mesafenin korunması: Masa ve sandalyelerin fiziksel mesafe kuralına uygun olarak dizayn edilmesi,

o Fotoselli dezenfektan: Yeme-içme alanlarına girişte ve kolay ulaşılabilecek yerlerde fotoselli dezenfektan standlarınin kurulması,

o Dezenfeksiyon: Yeme içme alanlarının uygun dezenfeksiyon yöntemleri ile belirli periyotlarda dezenfekte edilmesi,

o Koruyucu malzeme: Personelin koruyucu malzeme (önlük, maske, eldiven ve siperlik) kullanması,

o İçecek servisi: İçeceklerin kapalı ve pipetlerin jelatin içerisinde servis edilmesi,

- Ambalajlı servis: Servis takımlarının misafir masaya oturduktan sonra ambalajılı bir şekilde bırakılması,

- A'la carte: Yemekler ve içeceklerin masaya servis edilmesi,

o Kullan at: Yeme içme ve temizlik malzemelerinin çoğunlukla kullan at şeklinde olacak malzemeden seçilmesi,

o Eğitim: Personelin alınacak tedbirlere yönelik sürekli eğitilmesi,

o Havalandırma: Havalandırmanın uygun yöntemlerle düzenli olarak yapılması olarak sıralanabilir.

Yiyecek-içecek hizmetleri, otellerde bulaş riskinin en yoğun olduğu bölümlerden birisidir. Özellikle müşterilerin sürekli restoranı kullanması beraberinde birçok riski taşımaktadır. Bu nedenle otel yöneticilerinin görüşlerine göre restoranlarda, özellikle sosyal mesafenin korunması gerekliliği ön plana çıkmaktadır. Özellikle servis personeli ile müşterilerin, müşteriler ile diğer müşterilerin fiziki mesafelerinin korunması çok önemlidir. İçeceklerin kapalı olması, servis malzemelerinin mümkün ise tek kullanımlık olması, restoranlarda da maske kuralına uyulması da alınabilecek tedbirler arasında yer almaktadır. Açık büfe hizmet veren restoranlarda, yiyeceklerin servis personeli tarafından ihtiyaca göre verilmesi, servis personelinin de gerekli koruyucu malzemeleri (maske, eldiven, önlük, siperlik vb.) sürekli olarak kullanması gerekmektedir. Son olarak, restoranlarda klima yerine doğal havalandırmanın sağlanması, klima kullanılacak ise hava sirkülasyonunun sağlıklı yapıldığı ürünlerin tercih edilmesi, restoranlardaki sirkülasyonun doğru planlanması gerekliliği vurgulanmıştır.

\subsubsection{Kat hizmetlerine yönelik alınabilecek temel tedbirler}

Yapılan içerik analizi ile birlikte kat hizmetlerine yönelik alınabilecek temel tedbirler kapsamında 10 başlık (kod) belirlenmiştir. Yapılan çalışma sonucunda belirlenen başlıklar (kodlar) doğrultusunda alınabilecek temel tedbirler;

o Fotoselli malzeme: Özellikle WC'ler olmak üzere ortak kullanım alanlarında ve odalarda mümkün olan her şeyin fotoselli olması, 
- Ortak kullanım alanlarımın dezenfeksiyon ve havalandırmast: Ortak kullanım alanlarının sıklıkla uygun yöntemlerle dezenfekte edilmesi ve havalandırılması,

o Fotoselli dezenfektan: Mümkün olan her alanda kolay ulaşılabilir yerlerde fotoselli dezenfektan standlarının kurulması,

o Temizlik: Temizliklerin bez yerine tek kullanımlık kağıt havlu ile yapılması,

- Odaların dezenfeksiyonu ve havalandırması: Odaların her gün uygun yöntemlerle dezenfekte edilmesi ve havalandirılması,

o Tekstil değişimi: Tekstil değişiminin her gün yapılması ve tekstil malzemesinin yüksek derecede yıkanması,

o Oda tahsisi öncesi işlemler: Odalar tamamen boşaltıldığında uygun yöntemlerle detaylı dezenfekte edilmesi ve havalandırması, bu işlemleri müteakip belirli bir süre boş bırakılması,

o Eğitim: Kat görevlilerinin belirli periyotlarla eğitilmesi,

o Tek kullanımlık malzeme: Odalarda mümkünse misafirlerin kullanımı için tek kullanımlık malzeme bulundurulması,

- Koruyucu malzeme: Kat görevlilerine uygun ekipman, kıyafet ve koruyucu malzeme desteği verilmesi olarak sıralanabilir.

Kat hizmetleri departmanı, müşterilere yönelik özellikle otel odalarında ve/veya genel alanlarda ortaya çıkabilecek bulaş riskini önlemek için birtakım tedbirler alması gereken departmanlardan birisidir. Müşterilerin, otelde konakladıkları süre zarfı boyunca en fazla vakit geçirdiği alanlardan birisi de odalarıdır. $\mathrm{Bu}$ nedenle, müşteri odalarının temizliğinin sağlanması, uygun bir şekilde havalandırılması, tekstil malzemelerinin sıklıkla değiştirilmesi gibi konular, otel yöneticileri tarafından kat hizmetleri departmanına yönelik başta gelen tedbir önlemlerini oluşturmaktadır. Özellikle salgın döneminde oda tahsisi yapılır iken çok dikkat edilmesi gerekmektedir. Otel yöneticileri, odalar tamamen boşaltıldıktan sonra odaların detaylı bir biçimde dezenfekte edilmesini sağlamalı ve havalandırma işlemini uygulatarak belirli bir süre odaların boş bırakılmasını sağlamalıdır. Otel yöneticilerine göre, odalarda tek kullanımlık malzemelerin bulundurulması sağlanmalıdır. Ayrıca kat hizmetleri personelinin gerekli koruyucu malzemeler ile çalışması bulaş riskini önemli düzeyde azaltmaktadır. Kısacası otel yöneticileri tarafından böyle bir salgın sürecinde personelmüşteri, müşteri-personel, müşteri-müşteri ve personel-personel arasındaki temasın azaltılması gerekliliğini vurgulanmaktadır.

\subsubsection{Diğer hizmetlere yönelik alınabilecek temel tedbirler}

Yapılan içerik analizi ile birlikte diğer hizmetlere yönelik alınabilecek temel tedbirler kapsamında 10 başlık (kod) belirlenmiştir. Yapılan çalışma sonucunda belirlenen başlıklar (kodlar) doğrultusunda alınabilecek temel tedbirler;

- Eğitim: Tesiste diğer hizmetlerde görevli tüm personelin eğitilmesi ve bilinçlendirilmesi,

- Koruyucu malzeme: Tüm personele koruyucu malzeme desteğinin verilmesi,

- Fiziksel mesafenin korunmast: Personelin kullanım alanlarında fiziksel mesafenin korunmasının sağlanması,

o Ateş ölçümü: Personelin uygun yöntemlerle tesise gelişlerinde ateşinin ölçülmesi,

o Ortak kullanım alanları: Hamam, sauna, fitness salonu gibi tüm alanların uygun yöntemlerle dezenfeksiyonu, havalandırılması ve fiziksel mesafenin korunmasının sağlanması,

o Bilgilendirme: Tüm kullanım alanlarında bilgilendirici levhaların bulundurulması,

o Sağllk hizmeti: 24 saat sağllk hizmetinin verilmesi,

o Animasyon: Animasyon yapılan salonlarda fiziksel mesafenin korunmasının sağlanması,

o Havuz suyu: Havuz suyundaki klor seviyesinin uygun düzeyde bırakılması ve kontrol edilmesi,

- Şezlong kullanımı: Sahil ve havuzda şezlongların fiziksel mesafeye uygun olarak yerleştirilmesi, her kullanım sonunda dezenfeksiyonu ve dezenfeksiyonu müteakip belirli süre hizmete açılmaması olarak sıralanabilir.

Yapılan araştırma neticesinde, otel yöneticileri tarafından önbüro, yiyecek-içecek ve kat hizmetleri departmanı dışında diğer hizmetlere yönelik de alınması gereken bir dizi tedbir bulunmaktadır. Özellikle animasyon programları ve otelde yapılan etkinliklerde maske ve sosyal mesafe kurallarına azami ölçüde dikkat edilmesi gerekmektedir. Çocuk kulübü gibi çocukların ve ailelerinin yoğun bir şekilde vakit geçirdikleri yerler için de 


\section{Y. Dündar - C. E. Silik - B. Ilgaz 12/4 (2020) 3776-3794}

ekstra tedbirler alınmalıdır. Bu gibi alanların mümkün olduğunca kullanım dışında tutulması, kullanım durumunda ise temizlik, mesafe, maske vb. kuralların azami ölçüde uygulanması gerekmektedir. Ayrıca sahil, plaj, havuz başı gibi alanlarda yer alan şezlongların belirli aralıklarla konulması, her kullanım sonrasında dezenfekte işlemlerinin yapılması ve belirli süre kullanım dışında tutulması gibi birtakım tedbirler de önem arz etmektedir. COVID-19 salgını ile ilgili tesis içerisinde sürekli olarak bilgilendirmeler yapılmalı, levhalar ve işaretlemeler uygun yerlerde bulundurulmalıdır. Bununla birlikte, tesis içerisinde 24 saat süre ile sağlık hizmeti verilmelidir. Herhangi bir müşterinin salgına yönelik şikayeti bulunması durumunda, izolasyon başta olmak üzere gerekli tedbirlerin alınması gerekmektedir.

\section{Sonuç ve Tartışma}

Çin'in Wuhan kentinde ortaya çıkan salgın, dünya ekonomisini derinden etkilemiştir. Dünya Sağlık Örgütü tarafından yeni tip bir korona virüsü olarak belirlenmiştir. Son olarak hastalığın adı, COVID-19 olarak kabul edilmiştir. Turizm sektörü, insan mobilitesini öngören bir yapıda olduğu için salgın döneminde dışarıda kendini güvende hissetmeyen bireyler turizm faaliyetlerine katılım gösterme konusunda tereddütlere sahiptir. Dolayısıyla potansiyel turistler kötü algılarının baskın gelmesi ile turistik etkinliklere katılım durumlarını erteleyebilmektedir. Bu nedenle işletmeler, salgından sonra turistik hareketliliği koruyabilmek için oldukça etkin bir atılım göstermek durumundadır.

Konaklama tesisleri kapsamında; zorunlu uygulamalar, misafirlerin otele girişleri, personele yönelik tedbirler, genel alanlarda (yatak odası, mutfak, yeme-içme üniteleri, yüzme havuzu, fitness salonu, animasyon salonları) düzenlemeler, güvenlik önlemleri, otel taşıtları, personel lojmanları, satın alma, haşere ve zararlılarla mücadele, atık yönetimi, acil durum ve izolasyon gibi konu başlıklarında bir dizi kriterler yer almaktadır. Konaklama tesislerinin, konukların sağlıklı ve güvenli bir şekilde hizmet alabilmesi için söz konusu tedbirlere uygun hareket etmesi gerekmektedir. Salgından her sektör gibi olumsuz bir şekilde etkilenen turizm sektöründe de alınan tedbirler ile birlikte zararı en aza indirme çabası bulunmaktadır. Bu nedenle, konaklama tesislerinin güvenli alanlar kurarak verecekleri hizmet, turizm sektörü bakımından oldukça hayati önem taşımaktadır.

Araştırmanın teorik ve pratik katkıları olmak üzere iki farklı alanda katkısı bulunmaktadır. İlk olarak, COVID19 salgınının yeni bir salgın olması nedeniyle literatürde bu alanda yapılacak çalışmalara ihtiyaç duyulmaktadır. Literatürde yer alan bazı çalışmalarda (Soehardi ve Untari, 2020; Jung vd., 2021; Türker, 2020; Kiper vd., 2020; Tuna ve Çelen, 2020) salgın; otel çalışanları, turizm akademisyenleri ve insan kaynakları uzmanları bakış açılarıyla ele alınmıştır. Fakat otel yöneticileri bakış açısıyla yapılan çalışmalara çok az (Filimonau vd., 2020) rastlanılmıştır. Filimonau ve diğerleri (2020) tarafından otel yöneticilerine yönelik yapılan çalışmada ise salgına yönelik tedbirlerden ziyade örgütsel dayanıklılık konusu ele alınmıştır. Çalışma sonucunda, işletmelerin salgın karşısında ayakta kalabilmeleri için kurumsal dayanıklılığ 1 ve kurumsal sosyal sorumluluk düzeylerini arttırması gerekliliği vurgulanmıştır. Bu nedenle yapılan bu çalışmada ise, salgına yönelik otel yöneticileri perspektifinden inceleme yapılmış ve literatürdeki boşluğa katkı sağlanması amaçlanmıştır. İkinci olarak çalışmada, turizm sektöründeki yöneticilere salgına yönelik alınması gereken tedbirler konusunda pratik katkılar sunulmaktadır. Yapılan mülakat sonucunda otel yöneticilerinin önbüro, yiyecek içecek ve kat hizmetleri departmanları ile diğer hizmetler noktasında alınması gereken tedbirlere yönelik önerileri ayrı ayrı sıralanmıştır. Departmanlar özelinde otel yöneticileri bakış açısıyla uygulanması gereken somut tedbirler sırasıyla açıklanmıştır. Araştırma sonucunda ön büro hizmetlerine yönelik temel tedbirler, yiyecek-içecek hizmetlerine yönelik temel tedbirler, kat hizmetlerine yönelik temel tedbirler ve oteldeki diğer hizmetlere yönelik temel tedbirler olmak üzere dört tema altında sonuçlar elde edilmiştir.

Ön büro hizmetlerine yönelik alınabilecek temel tedbirler kapsamında 13 başlık (kod) elde edilmiştir. Bu başlıklar; ateş ölçümü, fotoselli dezenfektan, dezenfeksiyon, maske dağıtımı, koruyucu malzeme, deskin muhafazası, fiziksel mesafenin korunması, numaratör kullanılması, deskin bölünmesi, ön büro malzemelerinin dezenfeksiyonu, online giriş-çıkış sistemi, bavulların taşınma yöntemi ve bilgilendirmedir. Katılımcıların değindiği ana başlıklar bu şekilde sıralanmıştır. Otel yöneticileri, ön büro hizmetleri kapsamında özellikle maske, mesafe ve hijyen kurallarının uygulanmasını istemektedir. Personellerin maske, siperlik, eldiven gibi teçhizatlar ile birlikte çalışmaları istenmektedir. Bununla birlikte, müşteriler ile olan temasın azaltılması ve müşteri ile önbüro personeli arasına paravan konularak işlemlerin gerçekleştirilmesi gerekliliğini belirtmektedir. Bu noktada, sosyal mesafe kavramı ön plana çıkmaktadır. Sosyal mesafe, pandemi 


\section{Y. Dündar - C. E. Silik - B. Ilgaz 12/4 (2020) 3776-3794}

sürecinde ortaya çıkan önemli kavramlardan birisidir. Literatürde genel olarak kişilerin, kendilerini ait hissettikleri gruptan farklı olan kişilere yönelik tercihen uyguladıkları bir eylem olarak ifade edilmektedir. Fakat salgın sürecinde sosyal mesafe kavramı, kişiler arası fiziki mesafe koymayı tanımlayan yeni bir anlamı işaret etmektedir (Gençyürek Erdoğan ve Yavuz, 2020). Özellikle c/i işlemleri esnasında oluşabilecek kalabalık ve bulaş riski için de numaratörler aracılığı ile sırayla giriş işlemlerinin gerçekleştirilmesi gerekliliğ̈i vurgulanmaktadır. Bununla birlikte, mümkünse online giriş-çıkış siteminin kullanılması gerektiği anlaşılmaktadır. Böylelikle sosyal mesafe kuralının uygulanması amaçlanmaktadır. Müşteri bavullarının taşınması ile ilgili olarak, gerekli dezenfekte işlemlerinin yapılması, bellboyların farklı bir asansör kullanması ve müşteri bavullarının müşteri odalarının kapısına bırakılması gibi tedbirler de belirtilmiştir. Önbüro departmanının, otele gelen müşterileri karşılayan ilk departman olması itibariyle önemi bir kat daha fazla olmaktadır. Çünkü olası bir soruna karşı otele giriş yapılmadan önce müdahale edilme şansı ve bulaş riskinin önlenmesi sağlanabilmektedir.

Otel yöneticileri bakış açısıyla önbüro departmanı ile ilgili doğrudan bir çalışmaya rastlanılmamıştır. Bu nedenle konu ile ilgili yakın çalışmalar incelenmiştir. Literatürde yapılan incelemeler sonucunda Acar (2020) tarafından yapılan çalışmada, COVID-19 salgınının turizm faaliyetleri üzerindeki etkileri araştırılmıştır. Çalı̧̧ma sonucunda, salgının ülke ekonomileri üzerinde uzun süre hissedilecek türden zararlar oluşturacağı, turizm sektörünün de bu zarardan doğrudan etkileneceği belirtilmiştir. Bu sonucu destekleyen başka bir çalışmada ise Hoque ve diğerleri (2020) tarafından, salgının özellikle Çin'deki ülke ekonomisini olumsuz etkilediği ve bu etkinin de ülkenin turizm sektörü üzerinde uzun vadeli bir tahribata neden olacağ1 belirtilmiştir (Silik vd., 2020).

İkinci olarak yiyecek-içecek hizmetlerine yönelik alınabilecek temel tedbirler kapsamında 10 başlık (kod) belirlenmiştir. Bu kodlar; fiziksel mesafenin korunması, fotoselli dezenfektan, dezenfeksiyon, koruyucu malzeme kullanımı, içecek servisi, ambalajlı servis, Ála carte servis, kullan at ürünler, eğitim verilmesi ve havalandırma ile ilgili tedbirlerdir. Yiyecek içecek departmanı, müşterilerin kalabalık olarak bir araya geldikleri, sosyal mesafenin en fazla ihlal edilebileceği ve sirkülasyonun en yoğun olduğu departmanların başında gelmektedir. Bu nedenle, yiyecek içecek departmanında alınacak tedbirler, bulaş riskini doğrudan etkileyebilmektedir. Bu kapsamda, öncelikle restoran, kafe, bar vb. gibi alanlarda sosyal mesafe, maske ve hijyen kurallarının azami bir biçimde uygulanması gerekmektedir. Yiyecek ve içecekler, servis personeli tarafından müşterilerin taleplerine göre karşılanmalıdır. Burada servis personelinin gerekli teçhizat (maske, siperlik, eldiven, önlük vb.) ile çalışması son derece önem arz etmektedir. Özellikle açık büfe restoranlarda, yiyeceklerin misafirler tarafından alınması bulaş riskini daha da arttırmaktadır. Bu nedenle açı büfe restoranlarda, görevli servis personeli tarafından müşteri tabaklarına, müşterilerin talepleri kadar yiyeceğin konulması sağlanmalıdır. Yemek salonlarındaki masaların düzeni sosyal mesafe kuralına uygun bir biçimde düzenlenmelidir. Özellikle restoranlarda tek kullanımlık çatal, bıçak, kaşık vb. gereçlerin kullanılması gerekmektedir. Kullan-at ürünlerin kullanılması bulaş riskini önemli düzeyde düşürecektir. İşletmelerin barlarında genellikle şişe, kutu içecek servislerine ağırlık verilmelidir. Bardaklar, salgına yönelik önemli bir risk taşıdığı için mümkün oldukça kullanılmamalıdır. Son olarak, restoran giriş-çıkışları otel personeli tarafından sürekli olarak kontrol edilmeli, restoran içerisinde maskesiz müşterilerin dolaşmasına izin verilmemeli, kurallara uymayan müşteriler nazik bir biçimde uyarılmalıdır.

Otel yöneticileri bakış açısıyla yiyecek içecek departmanı ile ilgili doğrudan bir çalışmaya rastlanılmamıştır. Bu nedenle konu ile ilgili yakın çalışmalar incelenmiştir. Literatürde yapılan incelemeler sonucunda Bucak ve Yiğit (2021) tarafından yapılan çalışmada, yiyecek içecek sektöründe mutfak departmanında yönetici olarak çalışan şeflerin COVID-19 salgını sonrasında meslek ve yiyecek içecek sektöründe ne gibi değişiklikler olmuş olabileceğine ilişkin görüşleri ele alınmıştır. Elde edilen sonuçlar, şeflerin çoğunluğunun, COVID-19 salgınından sonra geleceğe kötümser bir bakış açısıyla bakacağını ortaya koymaktadır. Araştırmanın en önemli bulgularından birisi de şeflerin, COVID-19 salgını sonrasında Türkiye'deki her şey dâhil ve açı büfe sistemini değiştirmek istemeleridir. Salgının yiyecek içecek sektörü üzerindeki kısa ve uzun vadeli etkilerini inceleyen başka bir çalışmada Chowdhury ve diğerleri (2020), kısa vadede işletme sermayelerinin yetersizliği, distribütörlerin sınırlı sayıdaki operasyonları gibi etkilerin şiddetli olacağını ortaya koymaktadır. Uzun vadede ise, firmaların yatırım getirisi, firmaların GSYIH katkısı ve fazla personel çalışması gibi çeşitli performans ölçütlerinin azalacağı belirtilmektedir. 


\section{Y. Dündar - C. E. Silik - B. Ilgaz 12/4 (2020) 3776-3794}

Üçüncü olarak kat hizmetlerine yönelik alınabilecek temel tedbirler kapsamında da 10 başlık (kod) belirlenmiştir. Bu kodlar; fotoselli malzeme, ortak alanların dezenfeksiyonu ve havalandırılması, fotoselli dezenfektan, temizlik teknikleri, odaların dezenfeksiyonu ve havalandırılması, tekstil değişimi, oda tahsisi öncesi işlemler, eğitim, tek kullanımlık malzeme kullanımı ve koruyucu malzeme olarak belirtilmiştir. Kat hizmetleri kapsamında dikkat edilmesi gereken en önemli alanlar, müşteri odaları ve havuz başı, genel tuvaletler gibi genel müşteri alanlarıdır. Özellikle müşteri odaları, müşterilerin otele girişinden itibaren titizlik ile temizlenmelidir. Öncelikle müşteriler odaya yerleşmeden önce ilgili odanın temizlenmiş ve iyi havalandırılmış olması gerekmektedir. Odaların içerisine maske, dezenfektan konulmalı, klima ve televizyon kumandası gibi ürünler muhafaza edilerek temizliği yapılmalıdır. Odalardaki tekstil malzemelerinin (çarşaf, yastık kılıfı vb.) değişimleri müşteri talepleri başta olmak üzere sıklıkla yapılmalıdır. İşletmedeki tuvalet, havuz başı gibi genel kullanım alanlarında sosyal mesafe ve maske kuralına çok dikkat edilmelidir. Bu konuda, otel personeli gerekli eğitimleri alarak bilinçlendirilmelidir.

Otel yöneticileri bakış açısıyla kat hizmetleri departmanı ile ilgili doğrudan bir çalışmaya rastlanılmamıştır. Bu nedenle konu ile ilgili yakın çalışmalar incelenmiştir. Literatürde yapılan incelemeler sonucunda Çakır ve Barakazı (2020) tarafından yapılan çalışmada, ekonomi ve diğer faktörler nedeniyle turizm sektöründen elde ettiği gelirleri kaybetmek istemeyen ülkelerin, salgına karşı başta vergi olmak üzere birçok finansal, danışmanlık ve destekleyici paketlerle destek olduğu belirlenmiştir. Bununla birlikte, salgına yönelik endişelerin de devam edeceği ifade edilmiştir.

Son olarak otelin diğer hizmetlerine yönelik alınabilecek temel tedbirler kapsamında da 10 başlık (kod) elde edilmiştir. Bu kodlar; eğitim, koruyucu malzeme, fiziksel mesafe, ateş ölçümü, ortak alanların dezenfeksiyonu, bilgilendirme, sağllk hizmeti, animasyon tedbirleri, havuz suyu ve şezlong konusundaki tedbirler olarak belirlenmiştir. Ancak araştırma ile ilgili belirtilmesi gereken önemli bir husus şudur ki; görüşmeler bakanlığın zorunlu tedbir ve sertifikasyon süreçleri başlamadan gerçekleştirilmiş olmasıdır. Otelde temel olarak bulunan önbüro, yiyecek içecek ve kat hizmetleri departmanlarında alınması gereken tedbirlerin yanı sıra sağlık, animasyon gibi diğer hizmetlerde de birtakım tedbirlerin alınması gerekmektedir. Özellikle salgın sürecinde, mümkün olduğunca çocuk kulübü açılmamalı, animasyon etkinlikleri kapsamında da takım sporları veya toplu oyun/eğlenceler tercih edilmemelidir. Diğer hizmetlerden belki de en önemlisi sağllk hizmetidir. Salgın sürecinde, otelde $7 / 24$ hizmet sunan bir sağlık personeli bulunmalıdır. Olası bir izolasyon durumunu erken teşhis edip ayırabilmek son derece önem arz etmektedir. Bununla birlikte, otelin her alanında, müssteri ve personellerin maske ve mesafe kurallarına azami ölçüde uymaları sağlanmalıdır. Ayrıca otel personeli belirli aralıklar ile COVID-19 salgınına yönelik eğitim almalıdır. Tayfun ve diğerleri (2010) tarafından yapılan çalışmada, işletmelerde verilen eğitimlerin çalışanların işletmeye karşı olan bağlılıklarını arttırdığı tespit edilmiştir. Bu nedenle salgına yönelik verilecek eğitimlerin de işgörenler üzerinde olumlu bir etki oluşturacağ 1 söylenebilmektedir (Tayfun vd., 2010). Ayrıca otellerde bulunan havuzların da kalabalık olduğu düşünüldüğünde, havuz suyunun sürekli olarak kontrol edilmesi ve gece-gündüz dezenfekte işlemlerinin yapılması gerekmektedir. Son olarak gerek havuzda gerekse de sahilde bulunan şezlongların belirli aralıklar ile yerleştirilmesi (sosyal mesafe kuralına uygun) ve temizliğinin etkin bir biçimde yapılması önerilmektedir.

$\mathrm{Bu}$ çalışma, Antalya ilinde bulunan beş yıldızlı otel işletmelerinin yöneticileri ile sınırlandırılmıştır. Antalya'da bulunan üç ve dört yıldızlı otellerin yöneticileri ve diğer illerdeki otel yöneticilerinin de görüşleri inceleme konusu olabilir. Ayrıca çalışmada, beş yıldızlı resort otel yöneticileri ile mülakat gerçekleştirilmiştir. Aynı mülakatın, şehir otelleri, butik oteller gibi farklı türlerdeki otellerin yöneticileri ile gerçekleştirilmesi faydalı olacaktır. Çünkü elde edilen sonuçlar, beş yıldızlı resort otel işletmelerine uygun tedbirleri kapsamaktadır. Farklı türdeki işletmelerde aynı sonuçlar elde edilemeyebilir.

Çalışmanın sonucunda elde edilen başlıklar ve içerikler göstermektedir ki otel yönetimleri korona virüs sonrası "yeni normal" olarak adlandırılan dönemde hijyen faaliyetlerine otelin her biriminde oldukça önem vermektedir. Bu durum potansiyel turistlerin otelde konaklamak için güvensizlik algılarının kırılmasına yardımcı olabilecek niteliktedir. Bu bakımdan yapılan bu çalışmanın gerek otel yöneticileri ve potansiyel turistlere fayda sağlaması açısından, gerekse de literatürdeki ilgili boşluğu doldurması bakımından önemli bir çalışma olacağı düşünülmektedir. Daha sonraki çalışmalarda farklı bölgeler veya farklı turistik işletme türleri ele alınarak karşılaştırmalı çalışmalar gerçekleştirilebilir. 


\section{KAYNAKÇA}

Acar, Y. (2020). Yeni koronavirüs (COVID-19) salgını ve turizm faaliyetlerine etkisi, Güncel Turizm Araştırmaları Dergisi, 4 (1), 7-21.

Arslan, E. ve Kendir, H. (2020). COVID-19 salgını sonrası yükselen trend kırsal turizm: Zile örneği, Türk Turizm Araştırmaları Dergisi, 4 (4): 3668-3683.

Bucak, T. ve Yiğit, S. (2021). The future of the chef occupation and the food and beverage sector after the COVID-19 outbreak: opinions of Turkish chefs, International Journal of Hospitality Management, 92, 102682.

Chowdhury, T., Sarkar, A., Paul, S. K. and Moktadir, A. (2020). A case study on strategies to deal with the impacts of COVID-19 pandemic in the food and beverage industry, Operations Management Research, $1-13$.

Çakır, P. ve Barakazı, M. (2020). Koronavirüs sürecinin turizm sektörüne etkisi ve salgına karşı alınan tedbirler, Anadolu Üniversitesi Sosyal Bilimler Dergisi, 20 (3), 313-332.

Çeti, B. ve Ünlüönen, K. (2019). Salgın hastalıklar sebebiyle oluşan krizlerin turizm sektörü üzerindeki etkisinin değerlendirilmesi (Evaluation of the effect of crisis due to epidemic diseases on the tourism sector), AHBVÜ Turizm Fakültesi Dergisi, 22 (2), 109-128.

Demir, M., Günaydın, Y. ve Demir, Ş. Ş. (2020). Koronavirüs (Covid-19) salgınının Türkiye'de turizm üzerindeki öncülleri, etkileri ve sonuçlarının değerlendirilmesi, International Journal of Social Sciences and Education Research, 6 (1), 80-107.

Denzin, N. K. and Lincoln, Y. S. (2008). The Landscape of Qualitative Research, New York: Sage.

Dilber, A. ve Dilber, F. (2020). Koronavirüs (COVID-19) salgınının bireylerin beslenme alışkanlıkları üzerindeki etkisi: Karaman ili örneği, Journal of Tourism and Gastronomy Studies, 8 (3), 2144-2162.

Erdoğan, Ç. ve Yamaç Erdoğan, Z. (2020). Turizmin COVID-19 direnci: Bakanlık perspektifinden turizmde normalleşme faaliyetleri- I. Çeyrek, Türk Turizm Araştırmaları Dergisi, 4 (4), 3358-3377.

Filimonau, V., Derqui, B. and Matute, J. (2020). The COVID-19 pandemic and organisational commitment of senior hotel managers, International Journal of Hospitality Management, 91, 102659.

Gençyürek Erdoğan, M. ve Yavuz, V. (2020). Markalarda coronavirüs etkisi: sosyal mesafe logoları, Işsletme Araştırmaları Dergisi, 12 (3), 2501-2514.

Gössling, S., Scott, D. and Hall, M. (2020). Pandemics, tourism and global change: a rapid assessment of COVID-19, Journal of Sustainable Tourism, 29, 1-20.

Guba, E. G. and Lincoln, Y. S. (1982). Epistemological and methodological bases of naturalistic inquiry, Educational Technology Research and Development, 30 (4), 233-252.

Haleem, A., Javaid, M. and Vaishya, R. (2020). Effects of COVID-19 pandemic in daily life, Current Medicine Research and Practice, 10 (2), 78-79.

Hoefer, A., Pampaka, D., Wagner, E. R., Herrera, A. A., Alonso, E. G., Lopez-Perea, N., Portero, R. C., HerreraLeon, L., Herrera-Leon, S. and Gallo, D. N. (2020). Management of a COVID-19 outbreak in a hotel in Tenerife, Spain, International Journal of Infectious Diseases, 96, 384-386.

Hoque, A., Shikha, F. A., Hasanat, M. W., Arif, I. and Hamid, A. B. A. (2020). The effect of coronavirus (COVID19 ) in the tourism industry in China, Asian Journal of Multidisciplinary Studies, 3 (1), 52-58.

https://covid19.saglik.gov.tr/, (Erişim Tarihi: 07.06.2020).

https://covid19.who.int/, (Erişim Tarihi: 07.06.2020).

https://covid19bilgi.saglik.gov.tr/depo/diger_kamu_kuruluslar/COVID19-

KonaklamaTesislerindeAlinmasiGerekenOnlemler.pdf, (Erişim Tarihi: 01.05.2020).

https://ktb.gov.tr/genel/belgelendirmesorgu.aspx?lang=tr\&category=1, (Erişim Tarihi: 07.06.2020). 
Y. Dündar - C. E. Silik - B. Ilgaz 12/4 (2020) 3776-3794

https:/tursab.org.tr/apps//Files/Content/8b368379-712e-4ca3-8425-69ae28b9f113.pdf, 04.06.2020).

https://www.dunya.com/gundem/turkiyede-otel-doluluk-orani-yuzde-29a-dustu-haberi-468404, Tarihi: 18.11.2020).

https://www.ktb.gov.tr/Eklenti/72780,genelge20206pdf.pdf?0, (Erişim Tarihi: 04.06.2020).

https://www.tga.gov.tr/turkiyenin-guvenli-turizm-programi-hakkinda/, (Erişim Tarihi: 04.06.2020).

https://www.tga.gov.tr/wp-content/uploads/2020/06/71490862Genelge.pdf, (Erişim Tarihi: 13.06.2020).

Jiang, Y. and Wen, J. (2020). Effects of COVID-19 on hotel marketing and management: a perspective article, International Journal of Contemporary Hospitality Management, 0959-6119.

Jung, H. S., Jung, Y. S. and Yoon, H. H. (2021). COVID-19: The effects of job insecurity on the job engagement and turnover intent of deluxe hotel employees and the moderating role of generational characteristics, International Journal of Hospitality Management, 92, 102703.

Karadeniz, E., Beyaz, F. S., Ünlübulduk, S. N. ve Kayhan, E. (2020). Covid-19 salgınının turizm sektörüne etkilerinin ve uygulanan stratejilerin değerlendirilmesi: otel yöneticileri üzerinde bir araştırma, Türk Turizm Araştırmaları Dergisi, 4 (4), 3116-3136.

Kerlinger, F. N. and Lee, H. B. (1999). Foundations of Behavioral Research, New York: Harcourt College Publishers.

Kiper, V. O., Saraç, Ö., Çolak, O. ve Batman, O. (2020). COVID-19 salgınıyla oluşan krizlerin turizm faaliyetleri üzerindeki etkilerinin turizm akademisyenleri tarafından değerlendirilmesi, Balıksir University The Journal of Social Sciences Institute, 23 (43), 527-551.

Kültür ve Turizm Bakanlığı, (2020a), 2019 Yılı Sınır İstatistikleri, https://yigm.ktb.gov.tr/TR-249709/yillikbultenler.html, (Erişim Tarihi: 02.06.2020).

Kültür ve Turizm Bakanlığı, (2020b), 2019 Yılı Konaklama İstatistikleri, https://yigm.ktb.gov.tr/TR201120/konaklama-istatistikleri.html, (Erişim Tarihi: 02.06.2020).

Kültür ve Turizm Bakanlığı, (2020c), Konaklama Tesisi İstatistikleri, https://yigm.ktb.gov.tr/TR-201131/tesisistatistikleri.html, (Erişim Tarihi: 02.06.2020).

Kültür ve Turizm Bakanlığı, (2020d), 2020 Yılı Turizm İstatistikleri, https://yigm.ktb.gov.tr/Eklenti/78391,turizmistatistikleri2020-3-ceyrekpdf.pdf?0, (Erişim Tarihi: 18.11.2020).

Nicola, M., Alsafi, Z., Sohrabi, C., Kerwan, A., Al-Jabir, A., Iosifidis, C., Agha, M. and $\quad$ Agha, $\quad$ R. (2020). The socio-economic implications of the coronavirus and COVID-19 pandemic: a review, International Journal of Surgery, 78, 185-193.

Orhan, Z. H. ve Tirman, N. (2020). Analysis of the impact of COVID-19 on different sectors in Turkey during early periods of the pandemic, Journal of Business Research-Turk, 12 (3), 2312-2326.

Patton, M. Q. (1987). How to Use Qualitative Methods in Evaluation, Newbury Park, CA: Sage.

Silik, C. E., Ilgaz, B. ve Dündar, Y. (2020). COVID-19 sonrası turist davranışlarının kuşak farklılıkları açısından çoklu uyum analizi (MCA) ile değerlendirilmesi, Ĭ̆dır Üniversitesi Sosyal Bilimler Dergisi, 24, 341-372.

Soehardi, S. and Untari, D. (2020). The effect of COVID-19 pandemic on hotel employees, hotel occopancy rates and hotel tax income in Jakarta, Indonesia, Systematic Reviews in Pharmacy, 11 (12), 964-972.

Stewart, C. J. and Cash, W. B. (1985). Interviewing: Principles and Practices, (4.th Edition.), Dubuque, IO: Wm. C. Brown Publication.

Şengel, Ü., Çevrimkaya, M., Işkın, M., Zengin, B. ve Sarışık, M. (2020). The effects of novel coronavirus (COVID-19) on hospitality industry: a case, Journal of Tourism and Gastronomy Studies, 8 (3), 1646-1667. 
Y. Dündar - C. E. Silik - B. Ilgaz 12/4 (2020) 3776-3794

Tayfun, A., Palavar, K. ve Çöp, S. (2010). İşgörenlerin eğitim ve örgütsel bağlllık düzeyleri arasındaki ilişki: Belek bölgesindeki beş yıldızlı otel işletmelerinde bir araştırma, İ̧šletme Araştırmaları Dergisi, 2 (4), 318.

Tuna, A. A. ve Çelen, O. (2020). İşletmelerin insan kaynakları yönetimi uygulamaları üzerinde COVID-19 pandemisinin etkileri, OPUS-Uluslararası Toplum Araştırmaları Dergisi, 16 (30), 2710-2759.

Türker, G. Ö. (2020). Covid-19 salgını turizm sektörünü nasıl etkiler? Turizm akademisyenleri perspektifinden bir değerlendirme, International Journal of Social Sciences and Education Research, 6 (2), 207-224.

Türkiye Otelciler Birliği (TÜROB), (2020), Turizm İşletmesi Belgeli Tesisler, http://www.turob.com/tr, (Erişim Tarihi: 02.06.2020).

UNWTO (Birleşmiş Milletler Dünya Turizm Örgütü), (2020), Global Guidelines to Restart Tourism. Tourism and COVID-19 Priorities for Tourism Recovery Global Guidelines, [İnternet], https://webunwto.s3.euwest-1.amazonaws.com/s3fs-public/2020-05/UNWTO-Global-Guidelines-to-Restart-Tourism.pdf, (Erişim Tarihi: 04.06.2020).

Wang, Q. and Su, M. (2020). A preliminary assessment of the impact of COVID-19 on environment-acase study of China, Science of the Total Environment, 728, 138915.

Yang, Y., Zhang, H. and Chen, X. (2020). Coronavirus pandemic and tourism: Dynamic stochastic general equilibrium modeling of infectious disease outbreak, Annals of Tourism Research, 83, 102913.

Yu, M., Li, Z., Yu, Z., He, J. and Zhou, J. (2020). Communication related health crisis on social media: a case of COVID-19 outbreak, Current Issues in Tourism, 23, 1-7.

Zambrano-Monserrate, M. A., Ruano, M. A. and Sanchez-Alcalde, L. (2020). Indirect effects of COVID-19 on the environment, Science of the Total Environment, 728, 138813. 